\title{
Modelling the impact of rapid tests, tracing and distancing in lower-income countries suggest optimal policies varies with rural-urban settings
}

\author{
Xilin Jiang ${ }^{1,2,3}$, Wenfeng Gong ${ }^{4}$, Ya Gao ${ }^{5}$, Christophe Fraser ${ }^{1}$, Chris Holmes ${ }^{1,2,6}$ * \\ ${ }^{1}$ Big Data Institute, Li Ka Shing Centre for Health Information and Discovery, University of \\ Oxford \\ ${ }^{2}$ Department of Statistics, University of Oxford \\ ${ }^{3}$ Wellcome Centre for Human Genetics, University of Oxford \\ ${ }^{4}$ Bill \& Melinda Gates Foundation, Seattle WA, USA \\ ${ }^{5}$ Department of International Health, Johns Hopkins University \\ ${ }^{6}$ The Alan Turing Institute, London, UK \\ ${ }^{*}$ Corresponding authors: \\ Wenfeng.Gong@gatesfoundation.org
}

Address: Unit 1901, Tower B, Ping An International Financial Center, No.1-3 Xinyuan South Road, Chaoyang District, Beijing 100027, PRC

\section{cholmes@stats.ox.ac.uk}

Address: Department of Statistics, University of Oxford, 24-29 St Giles', Oxford OX1 3LB, UK

Disclaimer: The findings and conclusions in this report are those of the authors and do not necessarily represent the official position of the Bill and Melinda Gates Foundation (BMGF).

\section{Financial \& competing interests disclosure:}

Wenfeng Gong is an employee at the Bill and Melinda Gates Foundation. Xilin Jiang and Ya Gao served as consultants to the BMGF. The authors have no other relevant affiliations or financial involvement with any organization or entity with a financial interest in or financial conflict with the subject matter or materials discussed in the manuscript apart from those disclosed. 


\section{Abstract \\ Background}

Non-pharmaceutical intervention (NPI) remains the most reliable COVID-19 containment tool for low- and middle-income countries (LMICs) given the inequality of vaccine distribution and their vulnerable healthcare systems. We aimed to develop mathematical models that capture LMIC demographic characteristics such as young population and large household size and assess NPI effectiveness in rural and urban communities.

\section{Methods}

We constructed synthetic populations for rural, non-slum urban and slum settings to capture LMIC demographic characteristics that vary across communities. We integrated age mixing and household structure into contact networks for each community setting and simulated COVID-19 outbreaks within the networks. Using this agent-based model, we evaluate NPIs including testing and isolation, tracing and quarantine, and physical distancing. We explored the optimal containment strategies for rural and urban communities by designing and simulating setting-specific strategies that deploy rapid diagnostic test, symptom screening, contact tracing and physical distancing. We performed extensive simulations to capture the uncertainty of outbreak trajectories and the impact of varying model parameters.

\section{Findings}

We found the impact of testing, tracing and distancing varies with rural-urban settings. In rural communities, we found implementing either high quality (sensitivity $>50 \%$ ) antigen rapid diagnostic tests or moderate physical distancing could contain the transmission. Additionally, antibody rapid diagnostic tests and symptom-based diagnosis could be useful for mitigating the transmission. In non-slum urban communities, we demonstrated that both physical distancing and case finding are essential for containing COVID-19 (average infection rate $<10 \%$ ). In slum communities, we found physical distancing is less effective compared to rural and non-slum urban communities. Lastly, for all communities considered, we demonstrated contact quarantine is essential for effective containment and is effective at a low compliance rate (30\%).

\section{Interpretation}

Our findings could guide setting-specific strategy design for different communities in LMICs. Our assessments also have implications on applying rapid diagnostic tests and symptom-based diagnosis for case finding, tracing and distancing in lower-income communities. 
medRxiv preprint doi: https://doi.org/10.1101/2021.03.17.21253853; this version posted March 20, 2021. The copyright holder for this preprint (which was not certified by peer review) is the author/funder, who has granted medRxiv a license to display the preprint in perpetuity.

\section{Introduction}

The severe acute respiratory syndrome coronavirus 2 (SARS-CoV-2), which causes the COVID-19, has rapidly spread worldwide since the end of 2019. (Zhu et al., 2020) Without effective pharmaceutical interventions (e.g., vaccines), many low- and middle- income countries (LMICs) rely on non-pharmaceutical interventions (NPIs) to control COVID-19, (Brauner et al., 2021; J. N. Nkengasong et al., 2020) such as physical distancing, travel restriction, and testing and tracing programs. While contributing to COVID-19 control, these NPIs may cause considerable damage to the economies as people put their life and work on hold. (Hodgins \& Saad, 2020) Therefore, evaluating the effectiveness of NPIs could inform government decisions and ease the burden on the economy and society. (Brauner et al., 2021)

Many COVID-19 containment policies rely on testing which can be challenging to implement in LMIC because of the limited clinical resources (Bong et al., 2020; Murthy et al., 2015) and laboratory capacities. (Hasell et al., 2020; J. Nkengasong, 2020) Specifically, the real-time reverse transcription-polymerase chain reaction (RT-PCR), the most common tool for detecting SARS-CoV-2, requires lab facilities that are insufficient in LMICs. (Corman et al., 2020; Shen et al., 2020) These limitations pose challenges for early detection of SARS-CoV-2 transmission, which is crucial to LMICs due to their vulnerable healthcare systems. Therefore, it is essential to leverage alternative testing methods, such as rapid diagnostic tests (RDT) based on antigen or host antibody detection (Jacobs et al., 2020; Krueger et al., 2020; Organization \& Others, 2020; Porte et al., 2020) which is less resource-demanding. Additionally, community healthcare workers could perform contact tracing and quarantine to further mitigate the SARS-CoV-2 transmission, which has been implemented successfully during HIV and Tuberculosis outbreaks. (Shapiro et al., 2012) Combining RDT, contact tracing and quarantine, we can increase the testing capacity, ensure early and accurate detection of infected cases, and to contain disease transmission and avoid complete lockdown.

In this study, we evaluated the dynamics of COVID-19 transmission in younger populations that are typical of LMICs and the effectiveness of testing, tracing and distancing. We constructed an 
medRxiv preprint doi: https://doi.org/10.1101/2021.03.17.21253853; this version posted March 20, 2021. The copyright holder for this preprint (which was not certified by peer review) is the author/funder, who has granted medRxiv a license to display the preprint in perpetuity.

It is made available under a CC-BY-ND 4.0 International license .

agent-based model using synthetic contact networks that reflect the demographic structures in lower-income communities. To account for the different infection rates across geographical locations, (Baqui et al., 2020; El-Sadr \& Justman, 2020), we simulated SARS-CoV-2 transmission in the rural, non-slum urban and slum settings of LMICs and captured the uncertainty of the epidemic sizes by replicating the simulation with bootstrap samples of contact networks. For each setting, we evaluated the impact of various testing methods with or without physical distancing on COVID-19 transmission. Our simulation results suggest combined strategies of testing, close contact tracing and moderate physical distancing could reduce the number of infections significantly. We also showed that RDT and symptom-based diagnosis could be deployed in several settings for better containment outcomes.

\section{Material and methods}

\section{Processing demographic data}

We cited the age distribution and household sizes from the United nation. (Department of Economic and Social Affairs, 2020; United Nation, 2017) (Supplementary Table 1) We considered three age groups $(0-14,15-25$ and $25+$ years old) for simplicity and to capture the susceptibility of the younger population and contact structure differences between younger and older groups. We cited the contact survey data from a study in Uganda to compute age-specific contact matrices, contact numbers, and contact distribution within households (le Polain de Waroux et al., 2018). To compare the model using different demographic data, we included projected contact matrices from Kenya, South Africa and Nigeria. (Prem et al., 2017) We chose Kenya and South Africa as their projected data were compared with empirical data in the cited study; we chose Nigeria as it is located in Western Africa and has a large population. When using the contact matrices in simulation, we scaled the contact matrix to match the average daily contact number under each community setting. (Table 1)

\section{Agent-based modelling}

We used an agent-based model and configured the communities based on the age distributions and household sizes in South Africa, Kenya, Nigeria, and Uganda. We modelled three different 
community settings for LMICs: non-slum urban areas, rural areas, and slums, which differ in parameters including household sizes, daily close contact numbers, and percentage of contact between members from the same household. (Food and Agriculture Organization, 2018) (Table 1) For each community setting, we simulated 20 synthetic populations, where each household composed of at least one adult above age 25 , and each household was assigned to a location on a two-dimensional plane. The contact networks for the synthetic population were configured for the corresponding household structure, age-specific contact matrices, and geographical clustering, using an Exponential Random Graph Model (ERGM). (Robins et al., 2007) See Supplemental Methods for details on the ERGM.

After constructing the synthetic populations with contact and household structure, we randomly choose one of the 20 synthetic populations and simulated COVID-19 transmission initiated by importing 2 cases. At each time step of a simulated outbreak, one realized contact network of ERGM was sampled to represent the daily dynamic of contacts. (Figure 1) Infection events were sampled among the contacts proportional to the transmissibility multiplied by generation time, which is a Weibull distribution that has a mode on the day of onset. (Sun et al., 2020) The day of onset for each infected individual was sampled from the cited incubation time distribution (Ferretti et al., 2020). The susceptibility of the younger group (0-14 years old) was set to $50 \%$ of that of the older group (15+ years old). (Davies et al., 2020; Zhang et al., 2020) Using the age-dependent susceptibility and basic reproduction number, we computed the next generation matrix and the transmissibility. (Supplementary Methods) At each infection event, we sampled whether an infected individual is asymptomatic using a Bernoulli distribution of probability equal to $30 \%$. (Table 1) For detailed parameterization of transmission dynamics, see Supplementary Methods.

We tested our model from two perspectives. Firstly, we tested if our model reflects the cited contact data and transmission dynamics by comparing the simulated contact distribution and generation time with the empirical data. (Figure 2) Secondly, we tested if the cited generation time and incubation time capture the temporal dynamics of transmission by comparing the 
medRxiv preprint doi: https://doi.org/10.1101/2021.03.17.21253853; this version posted March 20, 2021. The copyright holder for this preprint (which was not certified by peer review) is the author/funder, who has granted medRxiv a license to display the preprint in perpetuity. It is made available under a CC-BY-ND 4.0 International license .

growth curve in our simulation to those of the UK (March $10^{\text {th }}$ to March $24^{\text {th }}$ ) and China (January $9^{\text {th }}$ to January $23^{\text {rd }}$ ) (Z. Wu \& McGoogan, 2020) before lockdown. We assumed no major behavioural change in the populations and constant case discovery rates within the selected time interval for these two countries. Moreover, we compared the averaged outbreak trajectories of the four countries simulated, and proceeded with synthetic populations of Uganda, because no obvious deviation was observed (Supplementary Figure 1).

\section{NPI simulation}

We evaluated the impact of testing alone and in combination with other NPIs, which include contact tracing, quarantine, and physical distancing, for LMICs. (Figure 1B) The testing methods considered were PCR, antigen RDT and antibody RDT. We simulated that only individuals with symptoms and agree to be tested will receive testing. In our simulation, an infected individual with symptoms will be discovered at a rate which is the product of four parameters: healthcare seeking rate, test consent rate, sampling success rate and lab sensitivity of the test. Values and sources of testing parameters were summarised in Table 2.

Our simulation assumes a test is always performed with close contact tracing and quarantine, unless specified otherwise. We assumed only close contacts of confirmed cases who consent to be isolated will be tracked. Therefore, the overall quarantine rate is determined by the product of three parameters: isolation consent rate of the infector, tracing success rate (we assumed a tracing success rate equal to $100 \%$ for members within the same household of the infector) and quarantine consent rate of the contacts. Physical distancing was modelled by reducing the number of contacts outside the households. We simulated the effect of physical distancing by reducing the out-of-household contact number by $20 \%$ to $80 \%$ with $20 \%$ increments. We approximate the effective reproduction number Re under physical distancing by scaling $\mathrm{Re}$ proportionally to the average daily contact numbers.

To identify the effective NPIs for LMICs, we simulated combined testing strategies. The strategies evaluated included 1) a symptom-based quarantine with low compliance rate 
performed with PCR testing, 2) a symptom-based quarantine with low compliance rate performed with PCR testing and antibody RDT, 3) and antigen RDT in combination with PCR testing. (Supplementary Table 2) The availability of PCR testing is assumed to be affluent for non-slum urban areas, limited for slums and not available for rural areas. All three strategies were replicated with and without physical distancing for 200 outbreak trajectories to estimate the average daily incidence number. We simulated each trajectory for 100 days to guarantee that the transmission extincts within the synthetic population.

\section{Sensitivity analysis}

We performed the sensitivity analysis separately for baseline conditions and for intervened conditions. For the baseline conditions, we simulated outbreaks over grids of values for transmission and demographic variables that are assumed or could not be determined from literature. We computed $\mathrm{R}^{2}$ using the total infected number as the dependent variable to capture the proportion of variance explained by each variable. (Table 1). For the intervened conditions, we performed the same simulations over grids of values for testing and NPI variables. We computed the $\mathrm{R}^{2}$ using infected numbers under three different intervention strategies as the dependent variables and testing/NPI variables in Supplementary table 3 as independent variables. In total we have 2,028 simulation settings ( 3 community settings, 4 containing strategies and 169 values for the variables) which are listed in Supplementary table 4. For each simulation setting, we simulated 200 simulated trajectories of 100 days to obtain the bootstrap confidence interval (BCI) of the estimated infection numbers.

The code generated during this study is available at:

https://github.com/Winston-Gong/test for containment release

\section{Results}

\section{Effectiveness of testing and physical distancing}


medRxiv preprint doi: https://doi.org/10.1101/2021.03.17.21253853; this version posted March 20, 2021. The copyright holder for this preprint (which was not certified by peer review) is the author/funder, who has granted medRxiv a license to display the preprint in perpetuity. It is made available under a CC-BY-ND 4.0 International license .

When simulating single testing methods under the non-slum urban scenario, we found that using symptom-based diagnosis, PCR, antibody RDT or antigen RDT alone will isolate or quarantine more than $25 \%$ of the population and reduce the proportion of population infected as the isolation compliance rate increases. (Figure 3B) When isolation compliance rates are at optimistic levels (i.e. symptom-based $=20 \%$, test-based $=90 \%$ ), antigen RDT testing outperformed other methods and reduced the infection rate (computed as the proportion of population that are infected) to $47.4 \%$ [95\% BCI $45.8 \%-49.1 \%$ ].

When simulating physical distancing alone under the baseline condition, we found that the infection number reduces as the out-of-household contact number reduces. (Figure 3C) The transmission almost stopped when non-household contact number was reduced by $80 \%(\mathrm{Re}=$ 1.01), compared to the scenario without physical distancing $(\operatorname{Re}=2.48)$ where $72.4 \%$ [95\% BCI: $70.6 \%-74.2 \%$ ] of the population was infected. When simulating physical distancing with symptom-based diagnosis, PCR testing, antibody RDT or antigen RDT using the optimistic compliance rates for isolation and quarantine (Table 2), we found these detection and quarantine methods could mitigate the transmission. When physical distancing reduces $60 \%$ of non-household contact, using antigen RDT testing for isolation and quarantine performs the best by reducing infection rate to $14.1 \%$ (95\% BCI $12.5 \%-15.7 \%)$.

When simulating disease outbreak in relation to combined testing strategies (Supplementary Table 2), we found that the symptom-based diagnosis with auxiliary PCR testing (type 1 combined strategy) could provide better outcomes (48.9\% infected [95\% BCI: 46.4\% - 50.5\%]) than either method alone, while additional antibody testing (type 2 combined strategy) did not provide noticeable containment power (46.9\% infected). (Figure 3D) Antigen RDT testing with auxiliary PCR (type 3 combined strategy) provided the strongest mitigating effect, with $41.0 \%$ [95\% BCI: $39.4 \%-42.7 \%$ ] of the population infected. Though the combined effect of antigen RDT and PCR testing is not much stronger than using antigen RDT testing alone. When physical distancing reduces out-of-household contact number by $60 \%$, the transmission is delayed and the infection rate is reduced to $21.8 \%$. When type 3 combined strategy is performed with physical 
medRxiv preprint doi: https://doi.org/10.1101/2021.03.17.21253853; this version posted March 20, 2021. The copyright holder for this preprint (which was not certified by peer review) is the author/funder, who has granted medRxiv a license to display the preprint in perpetuity.

It is made available under a CC-BY-ND 4.0 International license .

distancing, the infection rate is reduced to 5.6\%. (Figure 4A) Combined, these results show that although combination strategies could mitigate the transmission in the non-slum urban setting, delaying the transmission with physical distancing is essential for containing the outbreaks.

\section{Transmission and containment in different community settings}

When simulated outbreaks under different community settings, we found the transmission in rural areas (Food and Agriculture Organization, 2018) were slower and the final epidemic sizes were smaller (29.2\% infected [95\% BCI: $26.6 \%$ - 31.9\%]) than the urban settings (Figure 4A, Supplementary Figure 2, Supplementary Table 2). Using antigen RDT for case finding and contact tracing could reduce the infection rate to $11.6 \%$ [95\% BCI: $10.1 \%-13.1 \%$ ]. When simulating a moderate physical distancing by blocking $40 \%$ out-of-household contacts in rural communities, we observed a significant containment of the outbreak (6.2\% infected), while adding antigen RDT for case finding and contact tracing could further reduce infection rate to 2.4\%. Results from the non-slum urban setting is the baseline community discussed in the previous section. Slum setting is simulated with a large household size (mean $=15)$ and a high proportion $(50 \%)$ of contacts between members from the same household. Infection rate is high (mean $=82.9 \%)$ and using antigen RDT with limited PCR tests could mitigate the transmission (infection rate 54.9\% [95\% BCI: 54.0\% - 55.9\%]). While physical distancing (reducing 60\% of out-of-household contacts) could only mitigate the transmission in slums (infection rate $=$ $64.0 \%$ ), applying case finding and contact tracing using antigen RDT and limited PCR tests could further reduce the infection rate to $32.6 \%$.

The distributions of infection rates show substantial uncertainty for rural areas and for non-slum

urban areas when physical distancing is in place. (Figure 4A, Supplementary Table 2) To account for the uncertainty, we defined the stochastic extinction events as the trajectories that infected less than $5 \%$ of the population. Under the three settings considered, the probability of stochastic extinction increases when testing, isolation and quarantine are implemented. When physical distancing and case finding using antigen RDT are implemented under the rural setting, 80\% of the simulated trajectories would lead to an stochastic extinction event, while stochastic 
medRxiv preprint doi: https://doi.org/10.1101/2021.03.17.21253853; this version posted March 20, 2021. The copyright holder for this preprint (which was not certified by peer review) is the author/funder, who has granted medRxiv a license to display the preprint in perpetuity.

It is made available under a CC-BY-ND 4.0 International license .

extinctions happened in $25 \%$ of the trajectories when no NPI is imposed. Under the non-slum urban setting, the stochastic extinction events happened in $44.5 \%$ of the trajectories when physical distancing and type 3 combined strategy are implemented, which is a much larger proportion compared to $4 \%$ when no NPI is implemented. For the slum setting, physical distancing (reducing $60 \%$ of out-of-household contacts) increases stochastic extinction rate slightly from $2 \%$ to $5 \%$. When physical distancing is supplemented with type 3 strategy, the stochastic extinction probability increases to $13.5 \%$.

\section{The impact of RDT sensitivity, tracing and assumed parameters}

The most effective containing strategy identified above involves antigen RDT whose sensitivity varies across studies. (Pilarowski et al., 2020; Scohy et al., 2020) When testing strategy involves antigen RDT, our simulations show that the containment effect increases as the RDT sensitivity increases. (Figure 4B) To reach a similar containment effect as in Figure 4A, which assumes an antigen RDT sensitivity of 56\% (70\% sampling success rate and $80 \%$ kit sensitivity), the kits deployed should have a sensitivity above $40 \%$.

For the role of contact tracing, we found when the quarantine compliance rate increased from $30 \%$ to $100 \%$ under the type 3 strategy, the average infection rate reduced from $15.7 \%$ to $9.5 \%$ in rural settings, from $53.2 \%$ to $36.5 \%$ in non-slum urban settings, and from $66.5 \%$ to $49.5 \%$ in slum settings. (Figure 4C) Note only contacts that are of isolated infectors and successfully traced are subject to the quarantine. With no close contact quarantine measures, the combination strategies show no significant effect on reducing infection numbers (Supplementary Figure 3). Moreover, we found that the number of infected individuals discovered by testing is less than those discovered by contact tracing when the contact quarantine compliance rate is above $25 \%$. (Supplementary Figure 4A)

The impact of other testing parameters on the containment outcomes are summarised in Supplementary table 3 using $\mathrm{R}^{2}$ and P-values. Among these parameters, strong correlation between isolation consent rates and containing effectiveness are observed for all strategies and 
medRxiv preprint doi: https://doi.org/10.1101/2021.03.17.21253853; this version posted March 20, 2021. The copyright holder for this preprint (which was not certified by peer review) is the author/funder, who has granted medRxiv a license to display the preprint in perpetuity.

It is made available under a CC-BY-ND 4.0 International license .

settings. Days from symptom onset to isolation, quarantine consent rate of contacts and tracing success rate are correlated with containing effectiveness in two urban settings, while less impactful in the rural setting. Duration of close contact tracing is only effective for type 2 strategy under all three settings, suggesting antibody RDT requires contact tracing through a longer period to be effective. Additionally, we found that starting testing and quarantine after $10 \%$ of the population are infected could protect $31 \%$ of the healthy population under a non-slum urban setting and $21 \%$ of the healthy population under the slum setting (Supplementary Figure 4B).

\section{Discussion}

Our primary goal in this study is to identify optimal COVID-19 containment policies for LIMCs where NPIs are critical due to their limited vaccine supply and hospital capacity. (Walker et al., 2020) To capture demographic characteristics of LMICs, notably younger population, large household sizes and large rural population, we designed our agent-based model from two perspectives. Firstly, we constructed synthetic population and contact networks that incorporate age profiles, household sizes and contact structures. Secondly, we configured three community settings which have contacts of different frequencies and distributions to study the transmission and containment of COVID-19 in rural and urban populations. The transmission dynamics and NPI effectiveness varies largely across community settings which is consistent with observations that outbreaks have very different scales among LMICs. (Makoni, 2020; Nordling, 2020) Therefore, containment strategies should be designed for specific settings: mild NPI in rural regions where activities are mostly outdoor might provide a similar containment effect as strict NPI in urban areas where contacts happen outside households but indoors. Our model discovered another level of variability where similar epidemic start points could result in completely different epidemic sizes. The distribution of epidemic sizes tends to follow a bimodal pattern where new cases either infect the majority of the population or end up in stochastic extinctions. This pattern is most manifest in rural settings where contacts are more clustered within households or in urban settings with physical distancing. 
medRxiv preprint doi: https://doi.org/10.1101/2021.03.17.21253853; this version posted March 20, 2021. The copyright holder for this preprint (which was not certified by peer review) is the author/funder, who has granted medRxiv a license to display the preprint in perpetuity.

It is made available under a CC-BY-ND 4.0 International license .

Our results also suggested antigen RDT could be applied for containing the epidemic. Though the containing power subjects to the test sensitivity and community scenario, our results suggested high quality kits that have a sensitivity above $50 \%$ for the rural setting and above $40 \%$ for urban settings will provide similar containment power shown in our simulation. However, the detrimental effect of false negative test results might negate the containment effect, which requires careful evaluation of the kit sensitivity in real-world settings. (Bock et al., 2017) Therefore, we propose to supplement antigen RDT to PCR tests in the urban settings where PCR tests are available. Other case finding methods including antibody RDT and symptom-based diagnosis are effective in rural settings or physically-distanced non-slum urban settings. Both settings have relatively small numbers of out-of-household contacts, which allows case finding and quarantine to slow down the spread. Note all the case findings are based on an optimistic assumption of isolation consent rate (i.e. symptom-based $=20 \%$, test-based $=90 \%$ ), which remains to be validated in real-world settings.

The effectiveness of physical distancing varies across community settings: in the rural setting, a moderate physical distancing alone could mitigate the transmission to an infection rate of lower than $10 \%$; in the non-slum urban setting, physical distancing is an essential supplement to testing and tracing if we want to reduce the infection rate to below 10\%; in the slum setting, physical distancing is less effective. In contrast, contact tracing is an essential component of containing strategy in all community settings. More importantly, contact tracing could provide containing power even when simulating a low quarantine consent rate of contacts (30\%) and a short tracing time (3 days). As many LMICs have field healthcare professionals who could perform contact tracing, (Shapiro et al., 2012) it would be a realistic and essential measure to contain the outbreaks, especially that we have shown that testing alone without contact tracing is not effective.

There are some limitations in our study. Firstly, our simulated population is an approximation to the communities in LMICs and is limited by the lack of empirical evidence from LMICs. Therefore, a majority of the parameters are set heuristically rather than by empirical evidence. 
medRxiv preprint doi: https://doi.org/10.1101/2021.03.17.21253853; this version posted March 20, 2021. The copyright holder for this preprint (which was not certified by peer review) is the author/funder, who has granted medRxiv a license to display the preprint in perpetuity.

It is made available under a CC-BY-ND 4.0 International license.

Our simulation might be improved using detailed demographic data for LMICs, such as those collected from the Office of National Statistics (ONS) in the UK. Secondly, like many simulation studies, we had to choose our parameters from empirical studies that are not consistent with each other. (Omori et al., 2020) This difficulty is most pronounced when we are setting the parameters for age-dependent susceptibility and asymptomatic rate of the infected. Lastly, we scaled up our model by replicating simulations on independent contact networks $(200,000$ individuals divided into 200 populations of 1,000 individuals) due to the computation constraint of fitting large network models. Compared to simulations on larger networks, (Hinch et al., 2020) our strategy could not capture preparedness triggered by cases from nearby communities or repeated introduction of cases. A simulation framework that simulates large contact networks might provide insights to better coordinate policies for large communities.

\section{Acknowledgement}

Computation used the Oxford Biomedical Research Computing (BMRC) facility, a joint development between the Wellcome Centre for Human Genetics and the Big Data Institute supported by Health Data Research UK and the NIHR Oxford Biomedical Research Centre. The views expressed are those of the authors and not necessarily those of the NHS, the NIHR or the Department of Health. We thank Microsoft China Co. Ltd. for computation power during the exploration stage of the study. We thank Yang Liu, Jiayao Lei and Mark Jit for discussion and comments on the manuscript. 


\section{Tables and Figures}

\begin{tabular}{|c|c|c|c|c|c|c|c|}
\hline \multirow{2}{*}{ Parameter } & \multicolumn{3}{|c|}{ Sensitivity analysis range } & \multicolumn{3}{|c|}{ Coefficient of determination } & \multirow{2}{*}{ References } \\
\hline & Rural & $\begin{array}{l}\text { Non-slum } \\
\text { urban }\end{array}$ & Slum & Rural & $\begin{array}{l}\text { Non-slum } \\
\text { urban }\end{array}$ & Slum & \\
\hline Population size & \multicolumn{3}{|c|}{1000} & $0.005(P=0.222)$ & $\begin{array}{c}0.001(P= \\
0.604)\end{array}$ & $\begin{array}{c}0.009(\mathrm{P}= \\
0.109)\end{array}$ & $\begin{array}{c}\text { (Food and } \\
\text { Agriculture } \\
\text { Organization, 2018) }\end{array}$ \\
\hline $\begin{array}{l}\text { Number of initial } \\
\text { infected patients }\end{array}$ & \multicolumn{3}{|c|}{2} & $0.24(P=0)$ & $0.064(P=0)$ & $0.022(P=0)$ & Assumed \\
\hline $\begin{array}{l}\text { Daily close contact } \\
\text { number }\end{array}$ & 7 & 13 & 14 & $0.879(P=0)$ & $0.806(P=0)$ & $0.855(P=0)$ & \begin{tabular}{|c|} 
(le Polain de \\
Waroux et al., \\
2018; Mossong et \\
al., 2017)
\end{tabular} \\
\hline $\begin{array}{l}\text { Average household } \\
\text { size and distribution }\end{array}$ & 5 (Uganda) & 5 (Uganda) & 15 (India) & \multicolumn{3}{|c|}{ NA } & $\begin{array}{c}\text { (Kumar et al., 2018; } \\
\text { United Nation, } \\
\text { 2017) }\end{array}$ \\
\hline $\begin{array}{l}\text { Percentage of } \\
\text { contact between } \\
\text { members of the } \\
\text { same household }\end{array}$ & $50 \%$ & $23 \%$ & $50 \%$ & $0.001(P=0.381)$ & $0.173(P=0)$ & $0.199(P=0)$ & \begin{tabular}{|c|} 
(le Polain de \\
Waroux et al., \\
2018; Mossong et \\
al., 2017)
\end{tabular} \\
\hline $\begin{array}{c}\text { Asymptomatic } \\
\text { proportion }\end{array}$ & \multicolumn{3}{|c|}{$30 \%(10 \%-90 \%)$} & $0.001(P=0.22)$ & $0(P=0.634)$ & $0(P=0.887)$ & $\begin{array}{c}\text { (Nishiura et al., } \\
\text { 2020; Nogrady, } \\
\text { 2020) }\end{array}$ \\
\hline $\begin{array}{l}\text { Asymptomatic } \\
\text { infection rate }\end{array}$ & \multicolumn{3}{|c|}{$20 \%(10 \%-90 \%)$} & $0(P=0.4)$ & $\begin{array}{c}0.001(P= \\
0.119)\end{array}$ & $\begin{array}{c}0.002(P= \\
0.066)\end{array}$ & Assumed \\
\hline $\begin{array}{c}\text { Healthcare seeking } \\
\text { rate }\end{array}$ & \multicolumn{2}{|c|}{$70 \%$} & $60 \%$ & $0.001(P=0.403)$ & $0(P=0.649)$ & $\begin{array}{c}0.002(P= \\
0.176)\end{array}$ & Assumed \\
\hline $\begin{array}{c}\text { Basic reproduction } \\
\text { number (RO) }\end{array}$ & 1.45 & 2.7 & 2.9 & \multicolumn{3}{|c|}{ NA } & $\begin{array}{l}\text { (Anderson et al., } \\
\text { 2020) }\end{array}$ \\
\hline
\end{tabular}


medRxiv preprint doi: https://doi.org/10.1101/2021.03.17.21253853; this version posted March 20, 2021. The copyright holder for this preprint (which was not certified by peer review) is the author/funder, who has granted medRxiv a license to display the preprint in perpetuity.

It is made available under a CC-BY-ND 4.0 International license .

\begin{tabular}{|c|c|c|c|}
\hline $\begin{array}{c}\text { Susceptibility for } \\
\text { younger population } \\
(<15 \text { years old })\end{array}$ & $50 \%$ & NA & (Davies et al., \\
\hline
\end{tabular}

Table 1: Summary of population characteristics and transmission parameters and their impact on transmission. Sensitivity analysis is performed for a parameter when the source is not available for at least one of the three community settings. The coefficient of determination $\left(\mathrm{R}^{2}\right)$ shows the proportion of variance in the infected number that is captured by the parameter; The P-values in the parentheses show the rate of type one error of rejecting the null hypothesis that the parameter is not correlated with infection number. Last column shows the sources for cited parameters.

\begin{tabular}{|c|c|c|c|c|c|}
\hline Parameter & Symptom & PCR & Antigen RDT & Antibody RDT & Data source \\
\hline Test consent rate & $100 \%$ & \multicolumn{2}{|c|}{$80 \%$} & $70 \%$ & Assumption \\
\hline Isolation consent rate & $20 \%$ & \multicolumn{3}{|c|}{$90 \%$} & Assumption \\
\hline $\begin{array}{l}\text { Antibody testing day (days } \\
\text { from onset) }\end{array}$ & \multicolumn{3}{|c|}{ NA } & 8 & Assumption \\
\hline $\begin{array}{l}\text { Days from symptom onset } \\
\text { to isolation (days) }\end{array}$ & 1 & 5 & 1 & 8 & Assumption \\
\hline $\begin{array}{l}\text { Duration that close } \\
\text { contacts are traced (days) }\end{array}$ & 3 & 5 & 3 & 8 & Assumption \\
\hline $\begin{array}{c}\text { Tracing success rate } \\
\text { (non-household contacts) }\end{array}$ & $85 \%$ & $80 \%$ & $85 \%$ & $75 \%$ & Assumption \\
\hline $\begin{array}{l}\text { Quarantine consent rate of } \\
\text { contacts }\end{array}$ & $50 \%$ & \multicolumn{3}{|c|}{$70 \%$} & Assumption \\
\hline Sampling success rate & NA & \multicolumn{2}{|c|}{$70 \%$} & $100 \%$ & $\begin{array}{c}\text { (Pilarowski et al., } \\
\text { 2020; Wölfel et al., } \\
\text { 2020; F. Wu et al., } \\
\text { 2020) }\end{array}$ \\
\hline Lab sensitivity & NA & $100 \%$ & $80 \%(10 \%-90 \%)$ & $90 \%$ & $\begin{array}{c}\text { (Li et al., 2020; } \\
\text { Pilarowski et al., } \\
\text { 2020; Scohy et al., } \\
\text { 2020) }\end{array}$ \\
\hline $\begin{array}{l}\text { Half of patient develop } \\
\text { detectable serological } \\
\text { response (Days from } \\
\text { infection) }\end{array}$ & \multicolumn{3}{|c|}{ NA } & 12 & $\begin{array}{l}\text { (F. Wu et al., } \\
2020)\end{array}$ \\
\hline $\begin{array}{c}\text { Transmission rate after } \\
\text { quarantine }\end{array}$ & \multicolumn{4}{|c|}{ Rural: $10 \%$; Non-slum urban: $10 \%$; Slum: $20 \%$} & Assumption \\
\hline
\end{tabular}


medRxiv preprint doi: https://doi.org/10.1101/2021.03.17.21253853; this version posted March 20, 2021. The copyright holder for this preprint (which was not certified by peer review) is the author/funder, who has granted medRxiv a license to display the preprint in perpetuity. It is made available under a CC-BY-ND 4.0 International license .

\begin{tabular}{|c|c|c|c|c|}
\hline Test kit availability & NA & $\begin{array}{c}\text { Rural: none } \\
\text { Non-slum urban: } \\
\text { unlimited } \\
\text { Slum: } 2 \text { per week } \\
\text { per } 1000 \text { people }\end{array}$ & Unlimited & $\begin{array}{c}\text { (Hasell et al., } \\
\text { 2020) }\end{array}$ \\
\hline
\end{tabular}

Table 2: Summary of testing and NPI parameters. Last column shows the sources for cited parameters; values of assumed parameters are used in the containment simulations shown in Figure 4, while separate sensitivity analyses are performed for each assumed parameter (Supplementary Table 3 and Supplementary Table 4). For rationales behind the chosen value for assumed parameters, see Supplementary Methods. 
(A) Simulation of disease transmission using contact networks

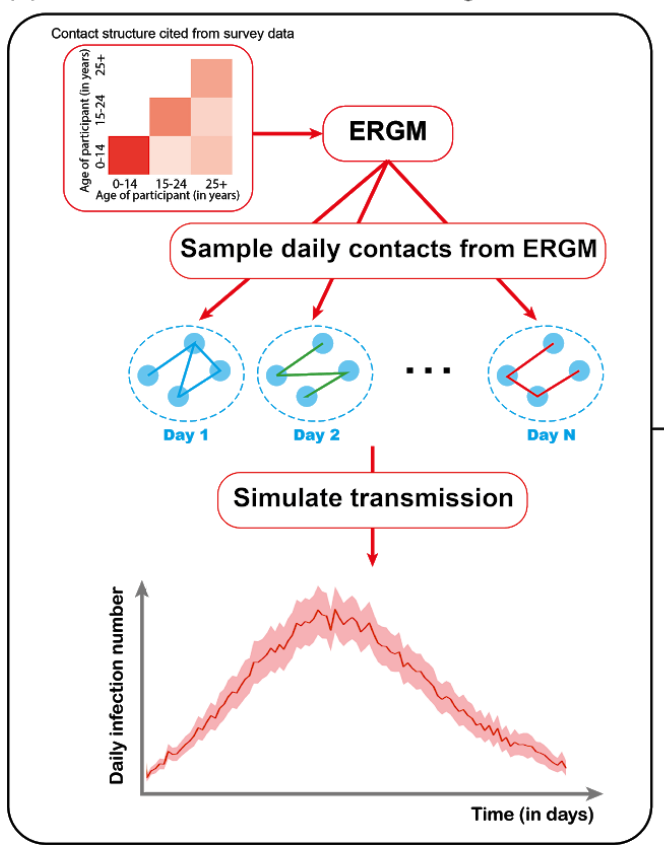

(B) Evaluation of non-pharmaceutical interventions

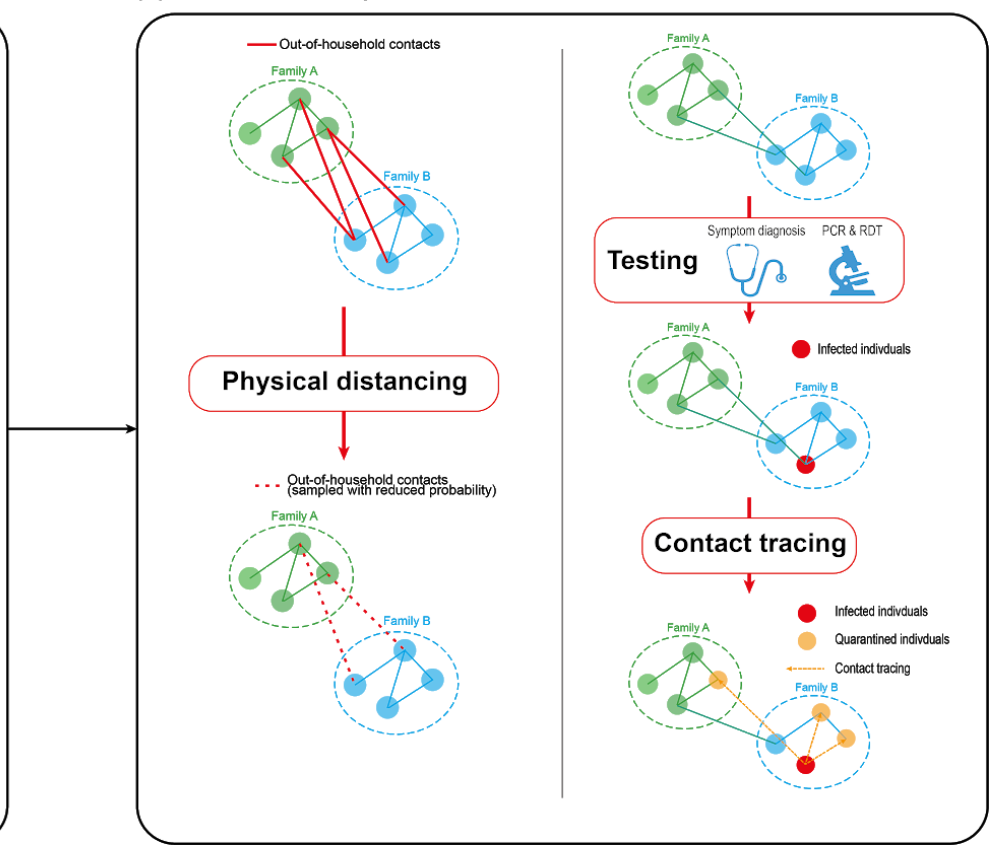

Figure 1: Schematic representation of methodology. A) For each parameter setting we simulated 20 synthetic populations and inferred the contact network with ERGM, using contact data over age groups and household structure. At each simulation step, a contact network is sampled from the ERGM, where we simulate the transmission of SARS-CoV-2. B) We evaluated the effect of physical distancing by reducing the sampling probability of out-of-household contacts. Detection, isolation, contact tracing and quarantine are also simulated using the contact networks. 
A

Day 20

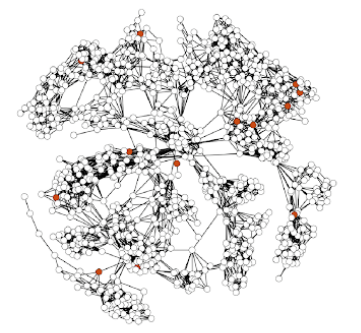

B

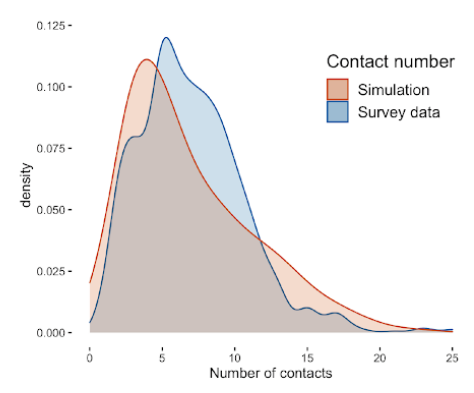

Day 30

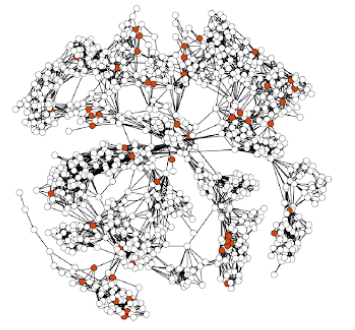

C

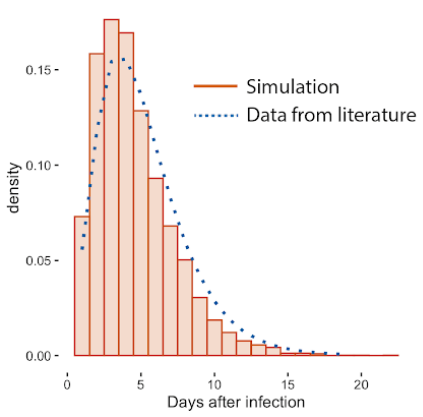

Day 40

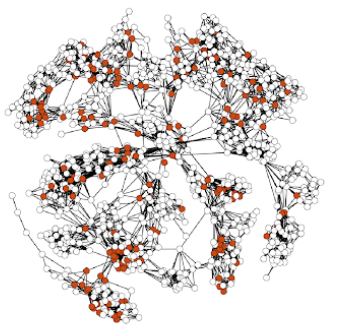

D

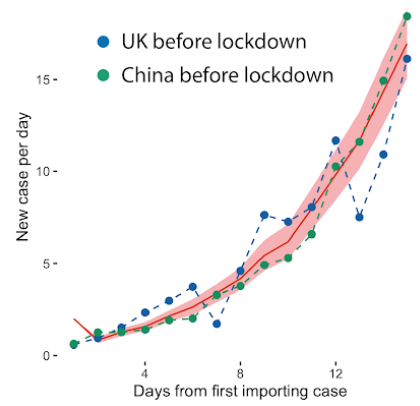

Figure 2: Properties of simulated outbreaks from the agent-based model. A) Example outbreak in a network composed of 1000 individuals, simulated under the non-slum urban setting without NPI. The left, middle and right panel show the distributions of infected individuals (red dots) on day 20, day 30 and day 40 from the day that initial cases are imported. The network structure is fixed for visualization, while in simulation a different contact network is sampled each day. B) Comparison of the simulated contact number distribution with those computed from the cited Uganda survey data. The simulated contact number distribution is computed by sampling 100 daily contact realizations from each of the 20 synthetic populations. C) Comparison of generation time from simulation (red histogram) and that from (Ferretti et al., 2020) (blue dotted curve). D) Comparison of simulated growth curves with cited data. The red curve with shade shows the mean of daily new cases and its $95 \%$ confidence interval for 15 days, computed from 200 simulated outbreak trajectories. The blue and green dashed curves show the growth curve for the UK (by report date) and China (by onset date) before lockdown. Growth curves are scaled so that they represent the same number of total infections. 


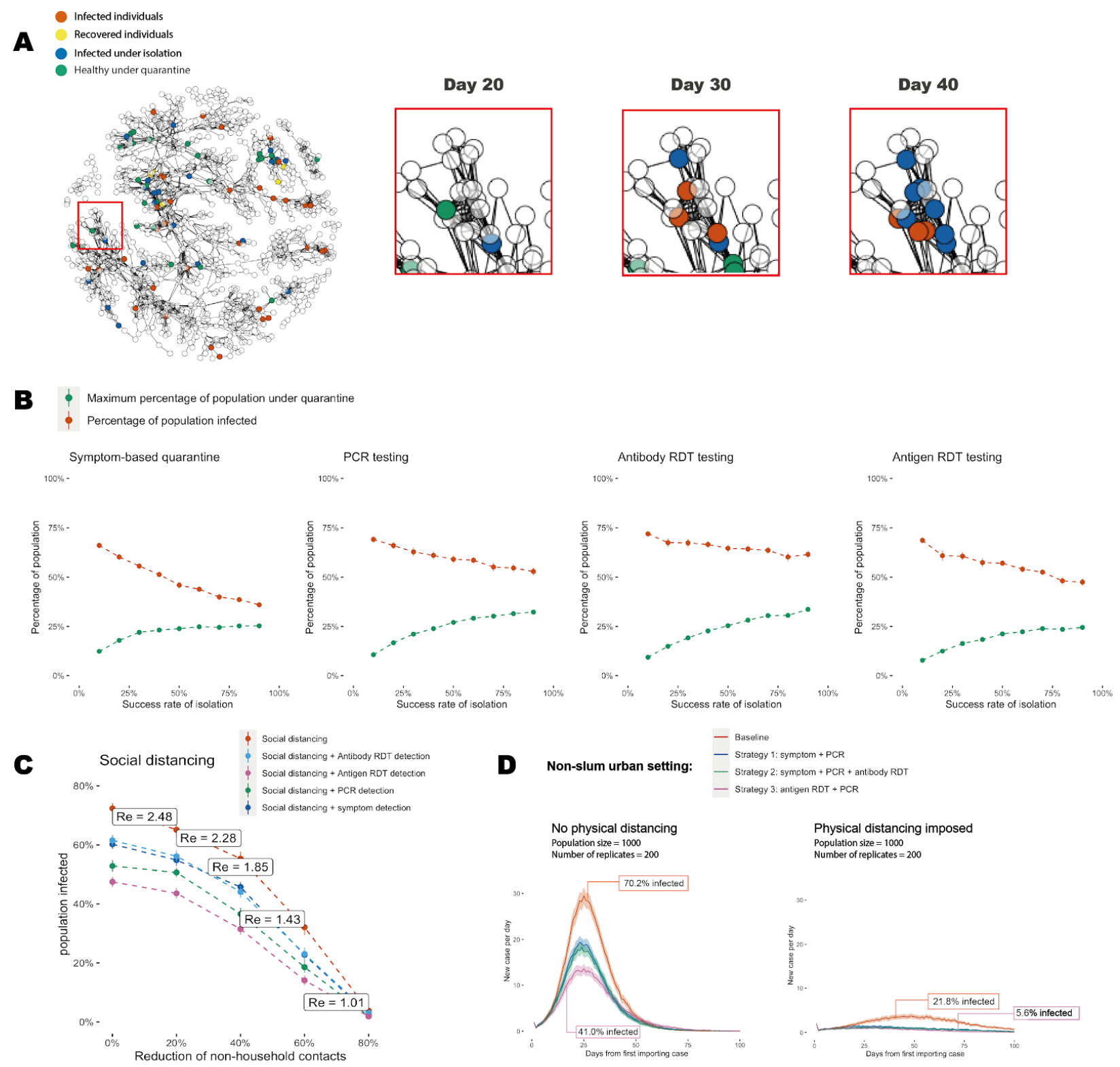

Figure 3: Evaluation of containing strategies. A) Example of case finding and quarantine in one simulated outbreak trajectory with NPIs, where a moderate physical distancing reduced $40 \%$ of the contact outside the household and the type 1 combined strategy is performed. (Supplementary Table 2) The network structure is fixed for visualization, while in simulation a 
medRxiv preprint doi: https://doi.org/10.1101/2021.03.17.21253853; this version posted March 20, 2021. The copyright holder for this preprint (which was not certified by peer review) is the author/funder, who has granted medRxiv a license to display the preprint in perpetuity. It is made available under a CC-BY-ND 4.0 International license .

contact network is generated each day. B) Proportion of population that are infected (at the end of the trajectories) and under quarantine (max value throughout the trajectories) using symptom, PCR, antibody RDT and antigen RDT as detection methods. The dots with bars show the mean value with $95 \%$ confidence interval from 200 simulated trajectories for each isolation compliance rate. C) Proportion of population infected when physical distancing blocks different proportions of out-of-household contacts. The box shows the corresponding effective reproductive number for the level of physical distancing. The combined effect of physical distancing with each testing method shown in B is plotted with different colors. D) Trajectories showing the number of daily cases when no intervention implemented (red), when onset isolation and PCR are performed (blue), when onset isolation, PCR and antibody RDT are all performed (green) and when antigen RDT testing are used with PCR testing (purple). The curves show the mean and the shaded area shows $95 \%$ bootstrap confidence interval from 200 trajectories. Left panel shows the baseline setting (non-slum urban) and the right panel shows the same setting with physical distancing imposed (60\% reduction of contact outside household, $\operatorname{Re}=1.57)$. 
medRxiv preprint doi: https://doi.org/10.1101/2021.03.17.21253853; this version posted March 20, 2021. The copyright holder for this preprint (which was not certified by peer review) is the author/funder, who has granted medRxiv a license to display the preprint in perpetuity.

It is made available under a CC-BY-ND 4.0 International license .

A Contact structure: Rural
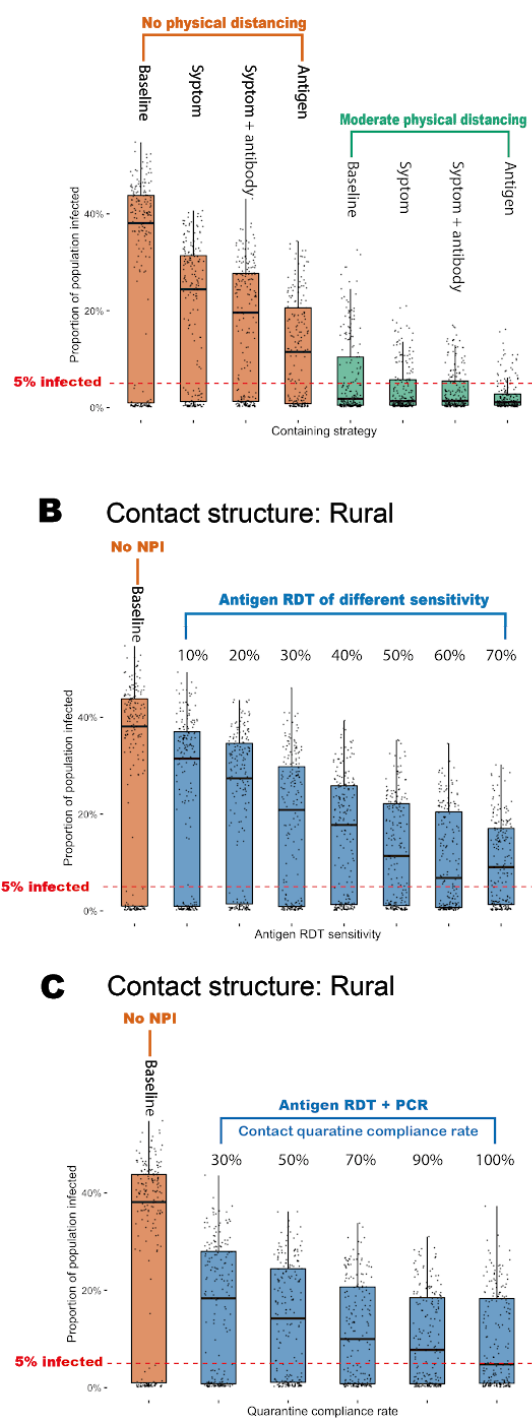
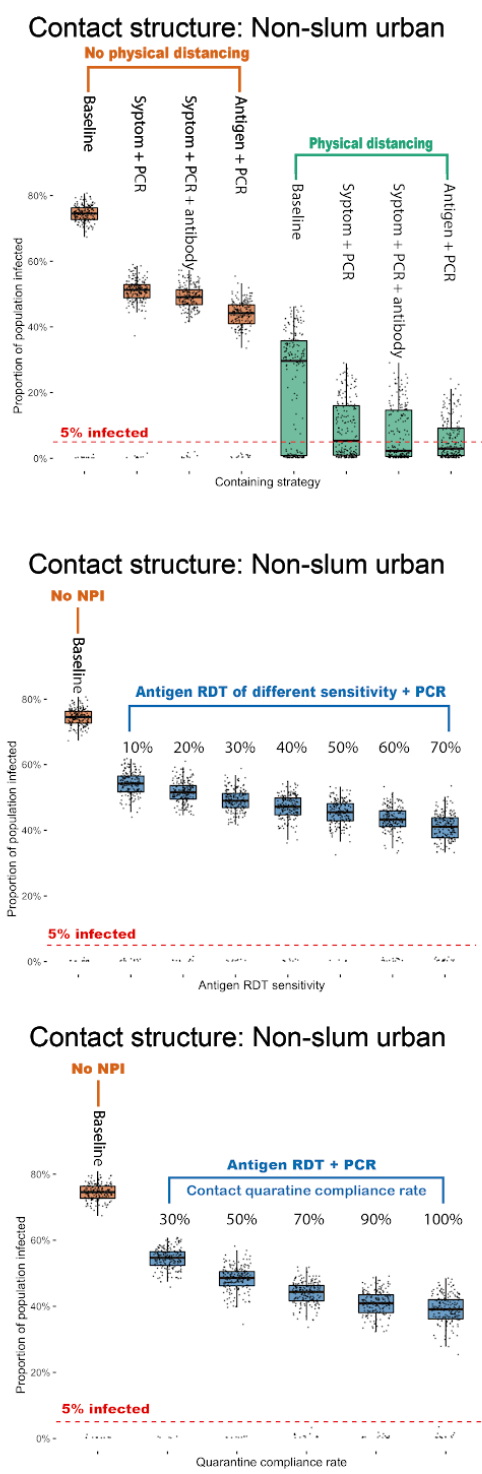
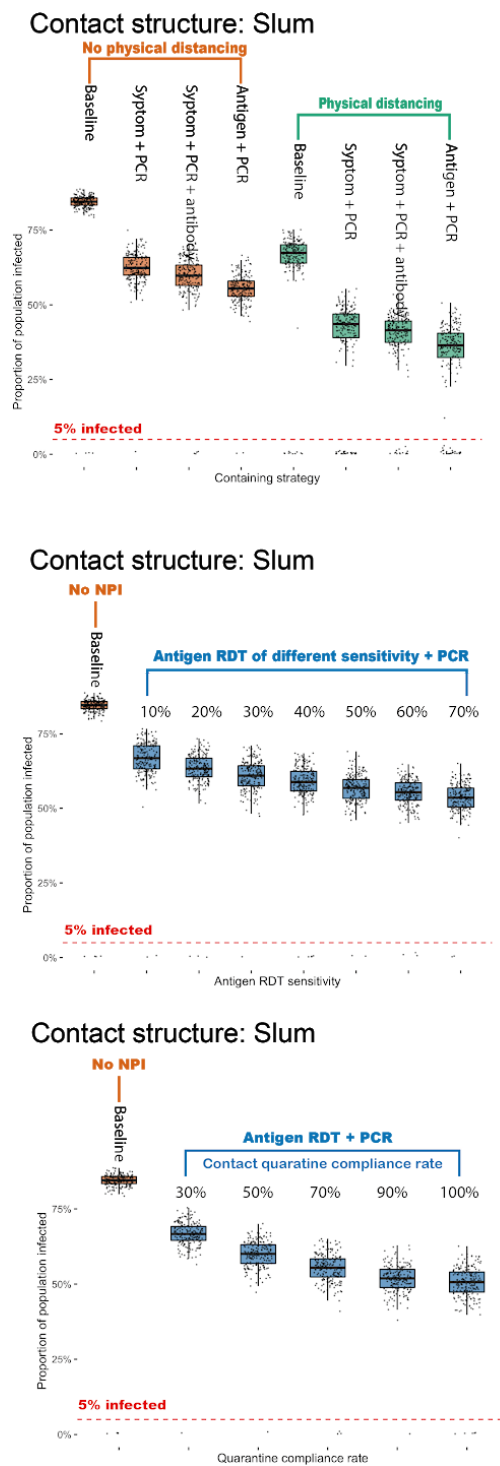

Figure 4: Boxplots of epidemic sizes under different simulation settings. A) Boxplots of infection rates under different containing strategies and in different community settings. For each of the three community settings, 200 simulations are performed for different NPI strategies, with (green boxes) or without physical distancing (orange boxes). B) Boxplots of infection rates for each community setting when applying antigen RDT of various sensitivity. The blue boxes show the infection rate when applying the most effective testing strategy identified in the upper panel, with different antigen RDT sensitivity. C) Boxplots of infection rates for each community setting when different quarantine compliances rates of traced contacts are simulated. The blue boxes show the infection rates when simulating containment using the most effective testing strategy 
medRxiv preprint doi: https://doi.org/10.1101/2021.03.17.21253853; this version posted March 20, 2021. The copyright holder for this preprint (which was not certified by peer review) is the author/funder, who has granted medRxiv a license to display the preprint in perpetuity.

It is made available under a CC-BY-ND 4.0 International license.

identified in the first panel. Each dot represents the epidemic size of one bootstrap trajectory. The red dashed line shows an infection rate at $5 \%$, dots below which are defined as stochastic extinction events. 


\section{Supplementary Tables and Figures}

\begin{tabular}{c|c|c|c|c} 
Age group (in years) & Uganda & South Africa & Kenya & Nigeria \\
\hline $0-14$ & $48.10 \%$ & $29.20 \%$ & $41.90 \%$ & $44.00 \%$ \\
\hline $15-24$ & $20.30 \%$ & $19.30 \%$ & $19.50 \%$ & $19.00 \%$ \\
\hline $25+$ & $31.60 \%$ & $51.50 \%$ & $38.60 \%$ & $37.00 \%$ \\
\hline Household Size (members) & & & & \\
\hline 1 & $11.00 \%$ & $27.00 \%$ & $19.00 \%$ & $16.00 \%$ \\
\hline $2-3$ & $22.00 \%$ & $35.00 \%$ & $28.00 \%$ & $26.00 \%$ \\
\hline $4-5$ & $27.00 \%$ & $23.00 \%$ & $30.00 \%$ & $26.00 \%$ \\
\hline $6+$ & $40.00 \%$ & $15.00 \%$ & $23.00 \%$ & $32.00 \%$ \\
\hline
\end{tabular}

Supplementary Table 1: Summary of the demographic information used in the study. The age and household sizes distribution are cited from the United Nation. (Department of Economic and Social Affairs, 2020; United Nation, 2017) 
medRxiv preprint doi: https://doi.org/10.1101/2021.03.17.21253853; this version posted March 20, 2021. The copyright holder for this preprint (which was not certified by peer review) is the author/funder, who has granted medRxiv a license to display the preprint in perpetuity.

\section{It is made available under a CC-BY-ND 4.0 International license .}

\begin{tabular}{|c|c|c|c|c|c|c|}
\hline \multirow{2}{*}{ NPIs } & \multicolumn{3}{|c|}{ Strategy detail } & \multicolumn{3}{|c|}{ Infection rate } \\
\hline & Rural & Non-slum urban & Slum & Rural & Non-slum urban & Slum \\
\hline No intervention & \multicolumn{3}{|c|}{ NA } & $29.2 \%(0.4 \%-46.7 \%)$ & $70.2 \%(70.5 \%-77.4 \%)$ & $82.9 \%(82.1 \%-86.6 \%)$ \\
\hline Type 1 combined strategy & $\begin{array}{l}\text { Onset isolation + } \\
\text { close contact } \\
\text { quarantine }\end{array}$ & $\begin{array}{c}\text { Onset isolation + PCR } \\
+ \text { close contact } \\
\text { quarantine }\end{array}$ & $\begin{array}{l}\text { Onset isolation }+ \\
\text { limited PCR + close } \\
\text { contact quarantine }\end{array}$ & $19.1 \%(0.4 \%-36.3 \%)$ & $48.9 \%(46.4 \%-55.0 \%)$ & $62.4 \%(57.2 \%-67.8 \%)$ \\
\hline Type 2 combined strategy & $\begin{array}{l}\text { Onset isolation + } \\
\text { antibody RDT + close } \\
\text { contact quarantine }\end{array}$ & $\begin{array}{c}\text { Onset isolation + PCR } \\
\text { + antibody RDT + close } \\
\text { contact quarantine }\end{array}$ & $\begin{array}{c}\text { Onset isolation + } \\
\text { limited PCR + antibody } \\
\text { RDT + close contact } \\
\text { quarantine }\end{array}$ & $16.5 \%(0.5 \%-0.5 \%)$ & $46.9 \%(44.2 \%-44.2 \%)$ & $58.9 \%(53.5 \%-53.5 \%)$ \\
\hline Type 3 combined strategy & $\begin{array}{l}\text { Antigen RDT + close } \\
\text { contact quarantine }\end{array}$ & $\begin{array}{l}\text { Antigen RDT + PCR + } \\
\text { close contact } \\
\text { quarantine }\end{array}$ & $\begin{array}{l}\text { Antigen RDT + limited } \\
\text { PCR + close contact } \\
\text { quarantine }\end{array}$ & $11.6 \%(0.3 \%-26.4 \%)$ & $41.0 \%(38.2 \%-48.5 \%)$ & $54.9 \%(49.9 \%-61.1 \%)$ \\
\hline Social distancing & $\begin{array}{l}\text { Reducing } 40 \% \text { of } \\
\text { non-household } \\
\text { contact }\end{array}$ & $\begin{array}{l}\text { Reducing } 60 \% \text { of non- } \\
\text { household contact }\end{array}$ & $\begin{array}{l}\text { Reducing } 60 \% \text { of non- } \\
\text { household contact }\end{array}$ & $6.2 \%(0.3 \%-19.1 \%)$ & $21.8 \%(0.3 \%-41.8 \%)$ & $64.0 \%(61.5 \%-71.9 \%)$ \\
\hline $\begin{array}{l}\text { Type } 1 \text { combined strategy + } \\
\text { social distancing }\end{array}$ & $\begin{array}{c}\text { Strategy } 1+\text { reducing } \\
40 \% \text { of non- } \\
\text { household contact }\end{array}$ & $\begin{array}{c}\text { Strategy } 1+\text { reducing } \\
60 \% \text { of non- } \\
\text { household contact }\end{array}$ & $\begin{array}{l}\text { Strategy } 1+\text { reducing } \\
60 \% \text { of non-household } \\
\text { contact }\end{array}$ & $4.0 \%(0.3 \%-11.8 \%)$ & $8.7 \%(0.4 \%-22.1 \%)$ & $38.3 \%(0.6 \%-49.8 \%)$ \\
\hline $\begin{array}{l}\text { Type } 2 \text { combined strategy + } \\
\text { social distancing }\end{array}$ & $\begin{array}{c}\text { Strategy } 2+\text { reducing } \\
40 \% \text { of non- } \\
\text { household contact }\end{array}$ & $\begin{array}{c}\text { Strategy } 2+\text { reducing } \\
60 \% \text { of non- } \\
\text { household contact }\end{array}$ & $\begin{array}{l}\text { Strategy } 2+\text { reducing } \\
60 \% \text { of non-household } \\
\text { contact }\end{array}$ & $3.6 \%(0.3 \%-10.8 \%)$ & $7.4 \%(0.3 \%-20.5 \%)$ & $38.6 \%(32.8 \%-46.7 \%)$ \\
\hline $\begin{array}{c}\text { Type } 3 \text { combined strategy + } \\
\text { social distancing }\end{array}$ & $\begin{array}{c}\text { Strategy } 3+\text { reducing } \\
40 \% \text { of non- } \\
\text { household contact }\end{array}$ & $\begin{array}{l}\text { Strategy } 3+\text { reducing } \\
60 \% \text { of non- } \\
\text { household contact }\end{array}$ & $\begin{array}{l}\text { Strategy } 3+\text { reducing } \\
60 \% \text { of non-household } \\
\text { contact }\end{array}$ & $2.4 \%(0.3 \%-6.7 \%)$ & $5.6 \%(0.3 \%-15.8 \%)$ & $32.6 \%(0.9 \%-44.0 \%)$ \\
\hline
\end{tabular}

Supplementary Table 2: Summary of NPI strategies for different settings and the mean of infection rate. The mean of infection rate is computed from 200 simulated trajectories of 100 days for each strategy. The range in the bracket shows the $10 \%$ and $90 \%$ quantiles of the infection rates from 200 bootstrap samples.

A) 
medRxiv preprint doi: https://doi.org/10.1101/2021.03.17.21253853; this version posted March 20, 2021. The copyright holder for this preprint (which was not certified by peer review) is the author/funder, who has granted medRxiv a license to display the preprint in perpetuity.

\section{It is made available under a CC-BY-ND 4.0 International license .}

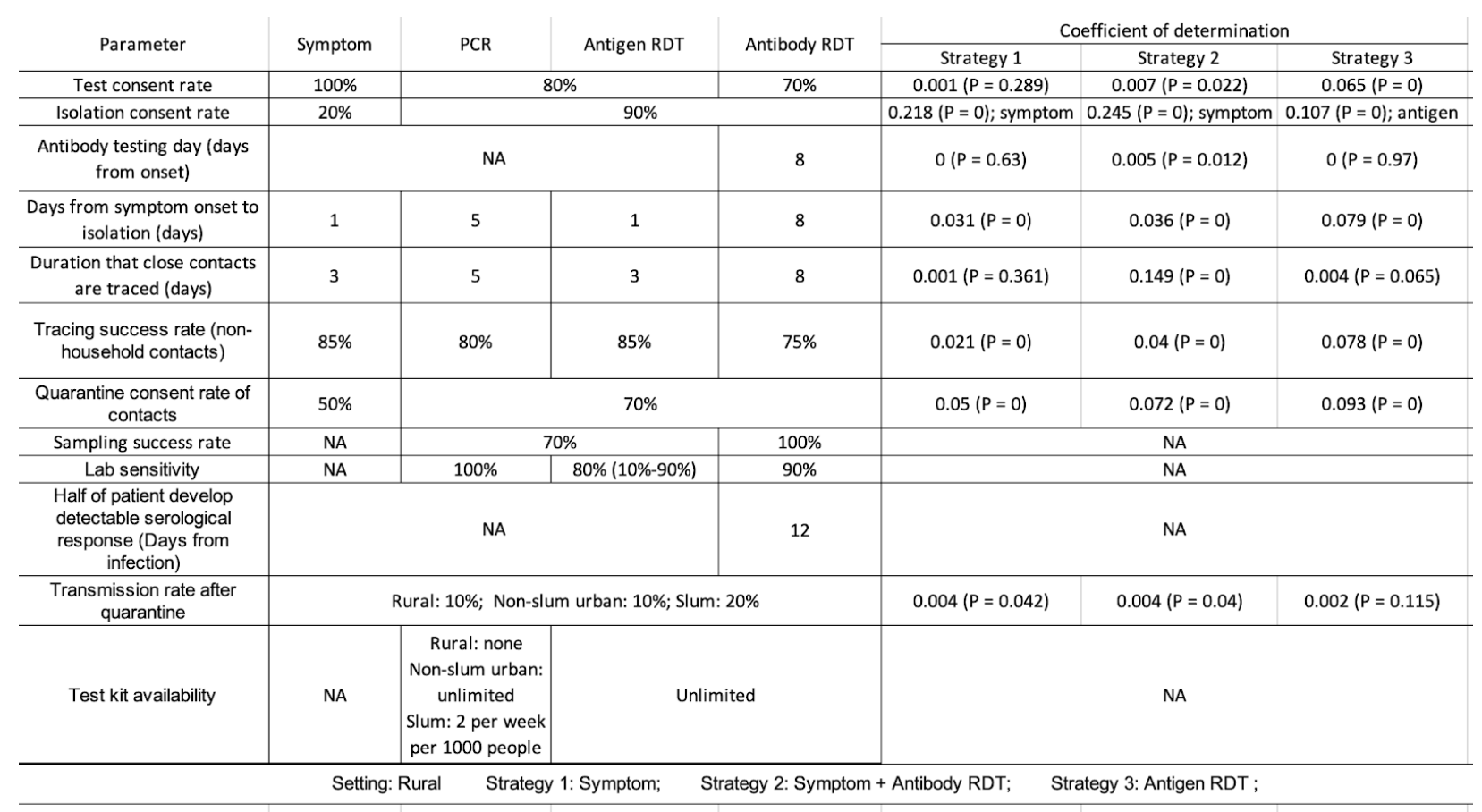

B)

\begin{tabular}{|c|c|c|c|c|c|c|c|}
\hline \multirow{2}{*}{ Parameter } & \multirow{2}{*}{ Symptom } & \multirow{2}{*}{ PCR } & \multirow{2}{*}{ Antigen RDT } & \multirow{2}{*}{ Antibody RDT } & \multicolumn{3}{|c|}{ Coefficient of determination } \\
\hline & & & & & Strategy 1 & Strategy 2 & Strategy 3 \\
\hline Test consent rate & $100 \%$ & \multicolumn{2}{|c|}{$80 \%$} & $70 \%$ & $0.028(P=0)$ & $0.056(P=0)$ & $0.187(P=0)$ \\
\hline Isolation consent rate & $20 \%$ & \multicolumn{3}{|c|}{$90 \%$} & $0.438(\mathrm{P}=0) ;$ symptom & $0.388(\mathrm{P}=0) ;$ symptom & $0.19(P=0)$; antigen \\
\hline $\begin{array}{l}\text { Antibody testing day (days } \\
\text { from onset) }\end{array}$ & \multicolumn{3}{|c|}{ NA } & 8 & $0(P=0.868)$ & $0(P=0.946)$ & $0(P=0.839)$ \\
\hline $\begin{array}{l}\text { Days from symptom onset to } \\
\text { isolation (days) }\end{array}$ & 1 & 5 & 1 & 8 & $0.16(P=0)$ & $0.173(P=0)$ & $0.287(P=0)$ \\
\hline $\begin{array}{l}\text { Duration that close contacts } \\
\text { are traced (days) }\end{array}$ & 3 & 5 & 3 & 8 & $0.002(P=0.166)$ & $0.317(P=0)$ & $0(P=0.787)$ \\
\hline $\begin{array}{l}\text { Tracing success rate (non- } \\
\text { household contacts) }\end{array}$ & $85 \%$ & $80 \%$ & $85 \%$ & $75 \%$ & $0.181(P=0)$ & $0.235(P=0)$ & $0.246(P=0)$ \\
\hline $\begin{array}{l}\text { Quarantine consent rate of } \\
\text { contacts }\end{array}$ & $50 \%$ & \multicolumn{3}{|c|}{$70 \%$} & $0.214(P=0)$ & $0.248(P=0)$ & $0.221(P=0)$ \\
\hline Sampling success rate & NA & \multicolumn{2}{|c|}{$30 \%$} & 0 & \multicolumn{3}{|c|}{ NA } \\
\hline Lab sensitivity & NA & $100 \%$ & $80 \%$ & $90 \%$ & \multicolumn{3}{|c|}{ NA } \\
\hline $\begin{array}{l}\text { Half of patient develop } \\
\text { detectable serological } \\
\text { response (Days from } \\
\text { infection) }\end{array}$ & \multicolumn{3}{|c|}{ NA } & 7 & \multicolumn{3}{|c|}{ NA } \\
\hline $\begin{array}{c}\text { Transmission rate after } \\
\text { quarantine }\end{array}$ & \multicolumn{4}{|c|}{ Rural: $10 \%$; Non-slum urban: $10 \%$; Slum: $20 \%$} & $0.033(P=0)$ & $0.03(P=0)$ & $0.096(P=0)$ \\
\hline Test kit availability & NA & $\begin{array}{c}\text { Rural: none } \\
\text { Non-slum urban: } \\
\text { unlimited } \\
\text { Slum: } 2 \text { per week } \\
\text { per } 1000 \text { people }\end{array}$ & & & \multicolumn{3}{|c|}{ Che } \\
\hline \multicolumn{2}{|c|}{ Setting: Non-slum urban } & Strategy 1: Sy & ptom + PCR; & trategy 2: Symp & $m+P C R+$ Antibody RD & Strategy 3: Antig & RDT + PCR; \\
\hline
\end{tabular}

C) 
medRxiv preprint doi: https://doi.org/10.1101/2021.03.17.21253853; this version posted March 20, 2021. The copyright holder for this preprint (which was not certified by peer review) is the author/funder, who has granted medRxiv a license to display the preprint in perpetuity.

It is made available under a CC-BY-ND 4.0 International license .

\begin{tabular}{|c|c|c|c|c|c|c|c|}
\hline \multirow{2}{*}{ Parameter } & \multirow{2}{*}{ Symptom } & \multirow{2}{*}{ PCR } & \multirow{2}{*}{ Antigen RDT } & \multirow{2}{*}{ Antibody RDT } & \multicolumn{3}{|c|}{ Coefficient of determination } \\
\hline & & & & & Strategy 1 & Strategy 2 & Strategy 3 \\
\hline Test consent rate & $100 \%$ & \multicolumn{2}{|c|}{$80 \%$} & $70 \%$ & $0.037(P=0)$ & $0.055(P=0)$ & $0.341(P=0)$ \\
\hline Isolation consent rate & $20 \%$ & \multicolumn{3}{|c|}{$90 \%$} & $0.448(P=0) ;$ symptom & $0.445(P=0) ;$ symptom & $0.32(P=0)$; antigen \\
\hline $\begin{array}{l}\text { Antibody testing day (days } \\
\text { from onset) }\end{array}$ & \multicolumn{3}{|c|}{ NA } & 8 & $0(P=0.886)$ & $0.016(P=0)$ & $0(P=0.847)$ \\
\hline $\begin{array}{l}\text { Days from symptom onset to } \\
\text { isolation (days) }\end{array}$ & 1 & 5 & 1 & 8 & $0.226(P=0)$ & $0.282(P=0)$ & $0.257(P=0)$ \\
\hline $\begin{array}{l}\text { Duration that close contacts } \\
\text { are traced (days) }\end{array}$ & 3 & 5 & 3 & 8 & $0.064(P=0)$ & $0.408(P=0)$ & $0.05(P=0)$ \\
\hline $\begin{array}{l}\text { Tracing success rate (non- } \\
\text { household contacts) }\end{array}$ & $85 \%$ & $80 \%$ & $85 \%$ & $75 \%$ & $0.289(P=0)$ & $0.365(P=0)$ & $0.367(P=0)$ \\
\hline $\begin{array}{l}\text { Quarantine consent rate of } \\
\text { contacts }\end{array}$ & $50 \%$ & \multicolumn{3}{|c|}{$70 \%$} & $0.354(P=0)$ & $0.471(P=0)$ & $0.267(P=0)$ \\
\hline Sampling success rate & NA & \multicolumn{2}{|c|}{$70 \%$} & $100 \%$ & \multicolumn{3}{|c|}{ NA } \\
\hline Lab sensitivity & NA & $100 \%$ & $80 \%(10 \%-90 \%)$ & $90 \%$ & \multicolumn{3}{|c|}{ NA } \\
\hline $\begin{array}{c}\text { Half of patient develop } \\
\text { detectable serological } \\
\text { response (Days from } \\
\text { infection) }\end{array}$ & \multicolumn{3}{|c|}{ NA } & 12 & & NA & \\
\hline $\begin{array}{c}\text { Transmission rate after } \\
\text { quarantine }\end{array}$ & \multicolumn{4}{|c|}{ Rural: $10 \%$; Non-slum urban: $10 \%$; Slum: $20 \%$} & $0.101(P=0)$ & $0.095(P=0)$ & $0.074(P=0)$ \\
\hline Test kit availability & NA & \begin{tabular}{|c|} 
Rural: none \\
Non-slum urban: \\
unlimited \\
Slum: 2 per week \\
per 1000 people
\end{tabular} & Unli & & & NA & \\
\hline
\end{tabular}

Supplementary Table 3: The impact of NPI parameter setting on the effectiveness of containment. Panel A-C shows sensitivity analysis under rural, non-slum urban and slum settings. The coefficient of determination $\left(\mathrm{R}^{2}\right)$ shows the proportion of variance in the final infected number (under each containing strategy) that is captured by the testing parameters; The $\mathrm{P}$-values in the bracket show the rate of type one error of rejecting the null hypothesis that the parameter is not correlated with outcome. 


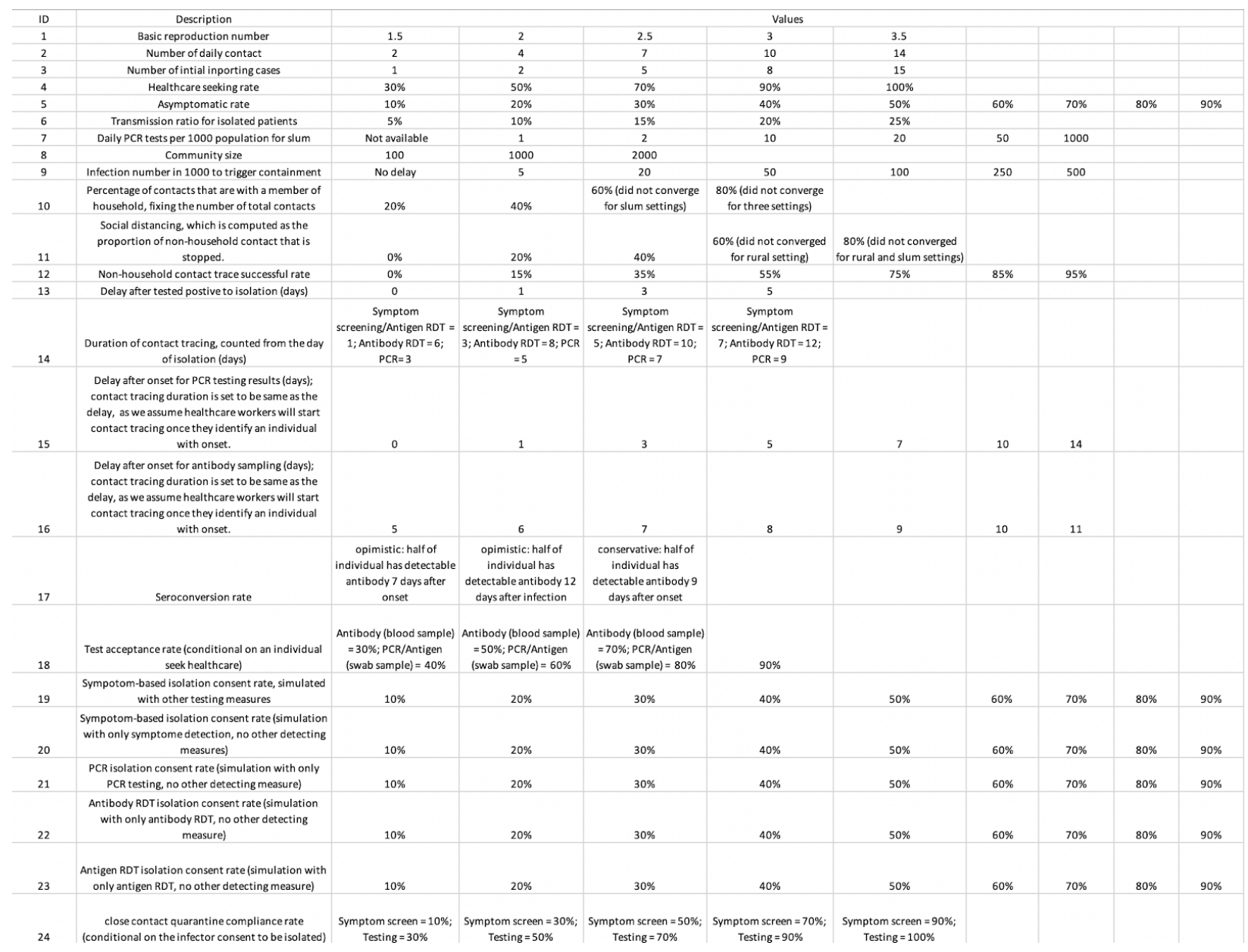

Supplementary Table 4: Parameter settings for sensitivity analysis. The Description explains what variables are changed and rows contain the values of each variable used for simulation. For each value we performed the simulation for baseline and three types of containing strategies under the rural, non-slum urban and slum settings. 
medRxiv preprint doi: https://doi.org/10.1101/2021.03.17.21253853; this version posted March 20, 2021. The copyright holder for this preprint (which was not certified by peer review) is the author/funder, who has granted medRxiv a license to display the preprint in perpetuity.

It is made available under a CC-BY-ND 4.0 International license .

\begin{tabular}{|c|c|c|c|c|c|c|}
\hline \multirow{2}{*}{$\frac{1 D}{2}$} & \multirow{2}{*}{$\begin{array}{c}\text { Description } \\
\text { Number of daily contact }\end{array}$} & \multicolumn{5}{|c|}{ Values } \\
\hline & & 2 & 4 & 7 & 10 & 14 \\
\hline & Rural & 0.99 & 1.00 & 1.00 & 1.00 & 0.14 \\
\hline & Non-slum urban & 1.00 & 1.00 & 0.99 & 1.00 & 1.00 \\
\hline & Slum & 1.00 & 0.94 & 0.99 & 1.00 & 1.00 \\
\hline \multirow[t]{4}{*}{9} & Community size & $\begin{array}{l}100 \text { (did not converge } \\
\text { for rural setting) }\end{array}$ & 1000 & 2000 & & \\
\hline & Rural & $0.000002 *$ & 1.00 & 1.00 & & \\
\hline & Non-slum urban & 1.00 & 1.00 & 1.00 & & \\
\hline & Slum & 1.00 & 1.00 & 1.00 & & \\
\hline \multirow[t]{5}{*}{11} & $\begin{array}{l}\text { Percentage of contacts that are with a member of } \\
\text { household, fixing the number of total contacts }\end{array}$ & $20 \%$ & $40 \%$ & $\begin{array}{l}60 \% \text { (did not converge } \\
\text { for rural setting) }\end{array}$ & $\begin{array}{l}80 \% \text { (did not converge } \\
\text { for three settings) }\end{array}$ & \\
\hline & Rural & 1.00 & 1.00 & 1.00 & $0^{*}$ & \\
\hline & Non-slum urban & 1.00 & 1.00 & $0.006^{*}$ & $0^{*}$ & \\
\hline & Slum & 0.99 & 1.00 & 1.00 & $0^{*}$ & \\
\hline & $\begin{array}{l}\text { Social distancing, which is computed as the } \\
\text { proportion of non-household contact that is } \\
\text { stopped. }\end{array}$ & $0 \%$ & $20 \%$ & $40 \%$ & $60 \%$ & $80 \%$ \\
\hline \multirow{3}{*}{12} & Rural & 1.00 & 1.00 & 0.99 & 1.00 & 1.00 \\
\hline & Non-slum urban & 1.00 & 1.00 & 1.00 & 1.00 & 1.00 \\
\hline & Slum & 1.00 & 1.00 & 1.00 & 1.00 & 1.00 \\
\hline
\end{tabular}

Supplementary Table 5: Lack-of-fit test for the ERGM inference. We performed lack-of-fit tests of the target statistics for the four variables that alter the ERGMs. IDs correspond to

Supplementary Table 3. For each value (bold), we compute the P-value by comparing the 20

fitted networks with the input to the ERGMs. * shows the cases when the networks are rejected as good fits.

$\mathbf{A}$

\section{B}

Fitted age-specific contact matrix

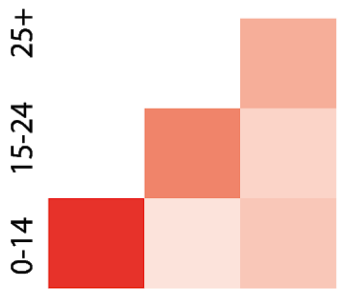

Age Group: $\quad 0-14 \quad 15-24 \quad 25+$

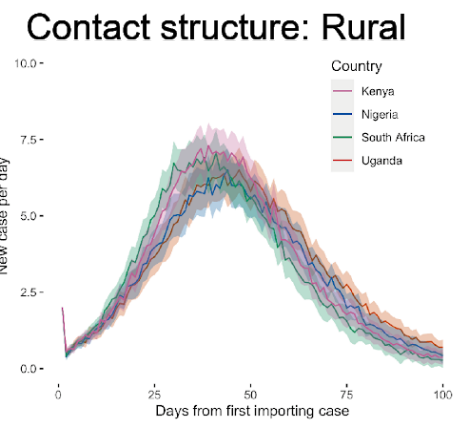

Empirical age-specific contact matrix

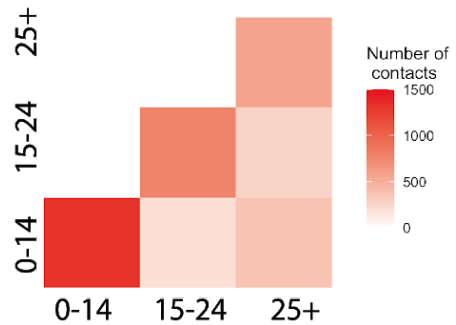

Contact structure: Urban

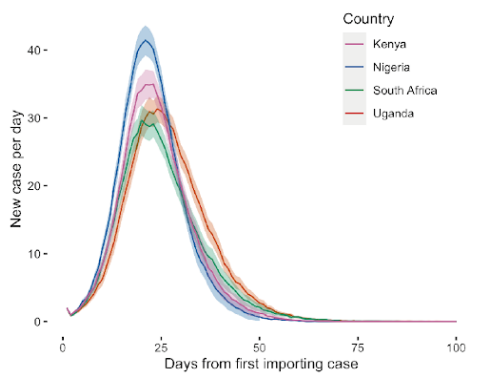

C

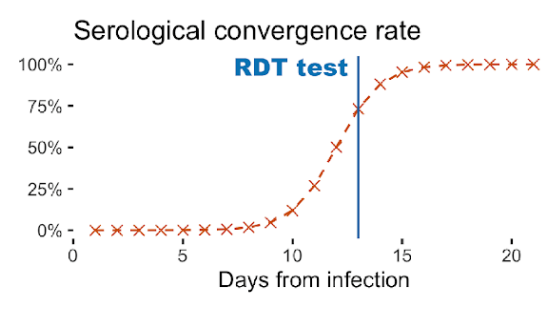


medRxiv preprint doi: https://doi.org/10.1101/2021.03.17.21253853; this version posted March 20, 2021. The copyright holder for this preprint (which was not certified by peer review) is the author/funder, who has granted medRxiv a license to display the preprint in perpetuity. It is made available under a CC-BY-ND 4.0 International license.

Supplementary Figure 1: A) Comparison of simulation using age distribution and household sizes for Kenya, Nigeria, South Africa and Uganda. B) Comparison of fitted age-mixing contact matrix with those cited from survey data. The color scale shows the total number of contacts for each mixing within the populations. C) Serological conversion rate cited for this study. (Wölfel et al., 2020) Blue vertical line shows the assumed time point when samples were collected after individuals were infected. 
medRxiv preprint doi: https://doi.org/10.1101/2021.03.17.21253853; this version posted March 20, 2021. The copyright holder for this preprint (which was not certified by peer review) is the author/funder, who has granted medRxiv a license to display the preprint in perpetuity.

It is made available under a CC-BY-ND 4.0 International license .
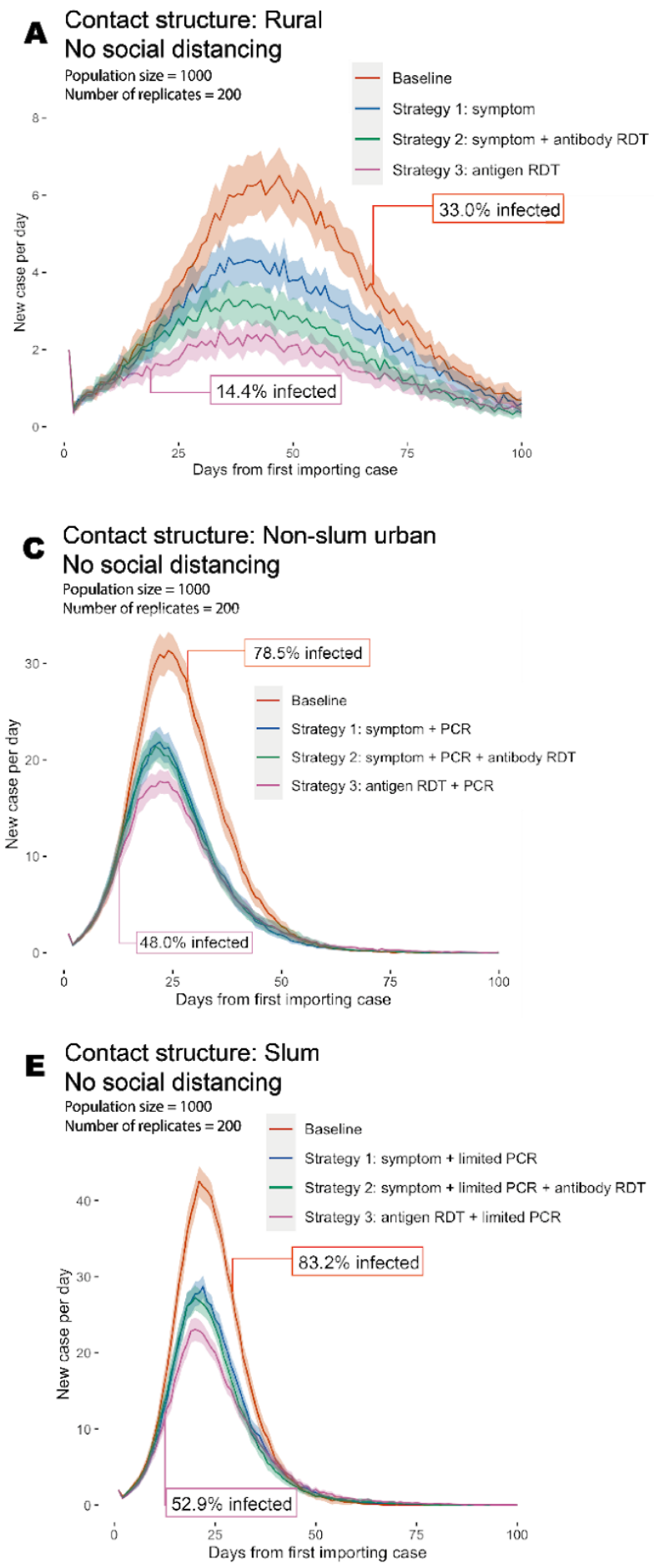

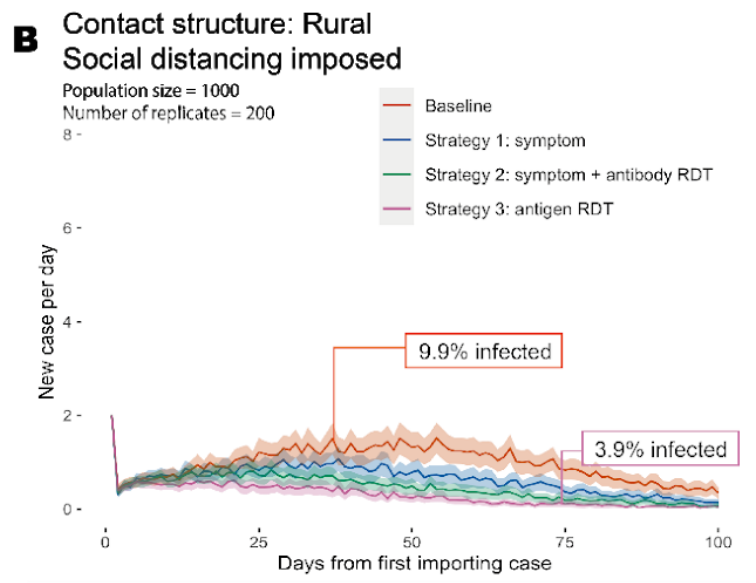

D Contact structure: Non-slum urban Social distancing imposed Population size $=1000$ Number of replicates $=200$

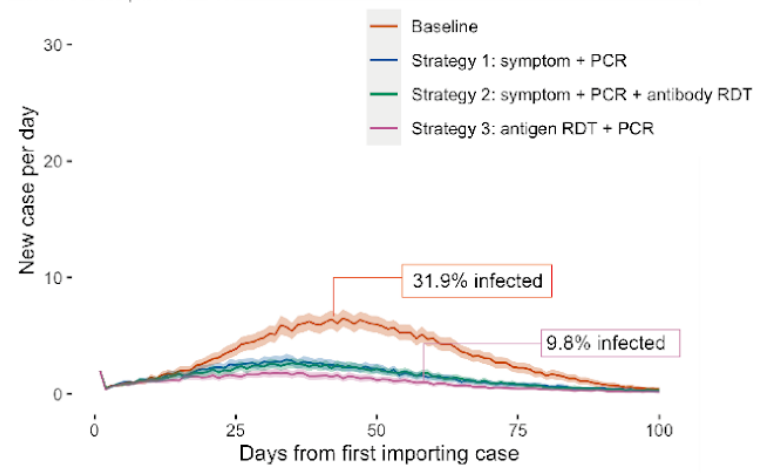

F Contact structure: Slum

Social distancing imposed

Population size $=1000$

Number of replicates $=200$

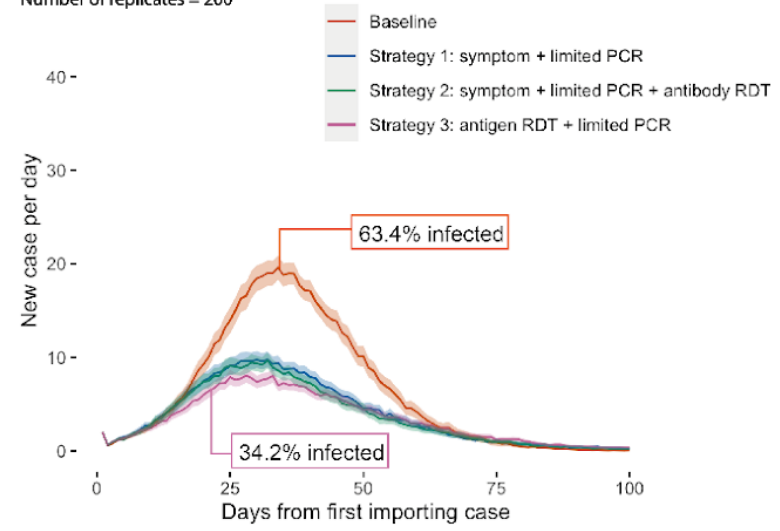

Supplementary Figure 2: Summary of averaged outbreak trajectories in rural, non-slum urban and slum settings. A-B) Averaged trajectories of outbreaks under rural setting and those with three NPI containing strategies. Left panel shows the simulation without physical distancing and the right panel shows simulation with a physical distancing that blocks $40 \%$ of non-household 
contacts. C-D) Same averaged trajectories under non-slum urban setting; Left panel shows simulation without physical distancing and right panel shows simulation with a physical distancing that blocks $60 \%$ of non-household contacts. E-F) Same averaged trajectories under slum setting; Left panel shows simulation without physical distancing and right panel shows simulation with a physical distancing that blocks $60 \%$ of non-household contacts. The curves are the mean value of daily infected numbers for a synthetic population of 1000; The shaded area indicated the $95 \%$ confidence interval of the estimation; Both mean and confidence intervals are computed from 200 simulated outbreaks. 
medRxiv preprint doi: https://doi.org/10.1101/2021.03.17.21253853; this version posted March 20, 2021. The copyright holder for this preprint (which was not certified by peer review) is the author/funder, who has granted medRxiv a license to display the preprint in perpetuity.

It is made available under a CC-BY-ND 4.0 International license .

Contact structure: Rural

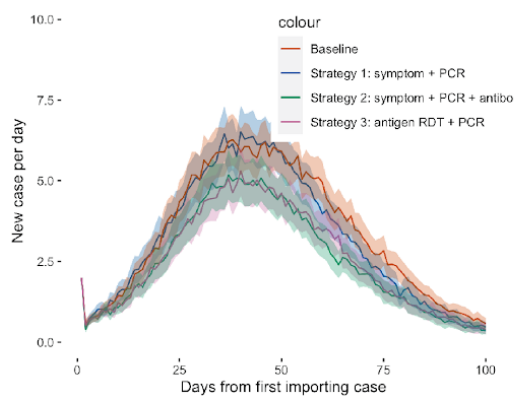

Contact structure: Non-slum urban

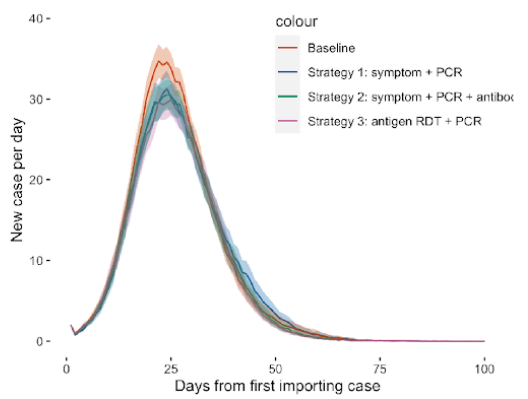

Contact structure: Slum

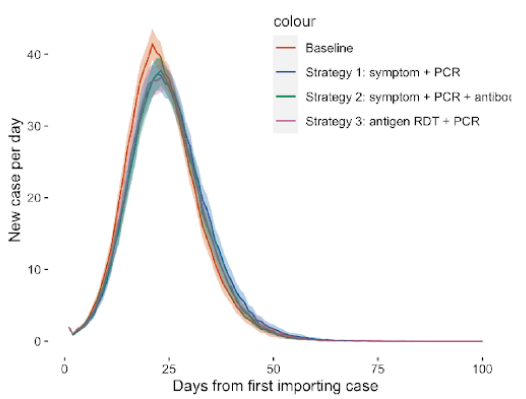

Supplementary Figure 3: Averaged trajectories when no close contact tracing is performed under rural, non-slum urban and slum settings. he curves are the mean value of daily infected numbers for a synthetic population of 1000; The shaded area indicated the $95 \%$ confidence interval of the estimation; Both mean and confidence interval are computed from 200 simulated outbreaks.

A Contact structure: Rural Strategy: Symptom

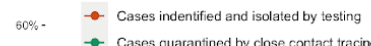

$\rightarrow$ Cases quarantined by close cortat trocing

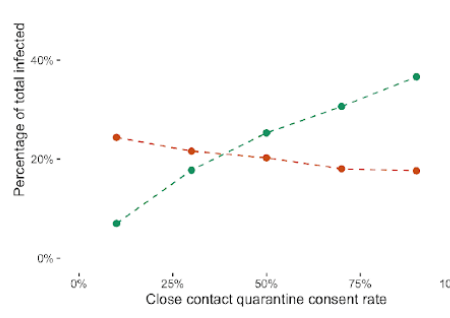

Contact structure: Rural

B Strategy: Antigen RDT
Contact structure: Non-slum urban Strategy: Symptom + PCR

$60 \%$.
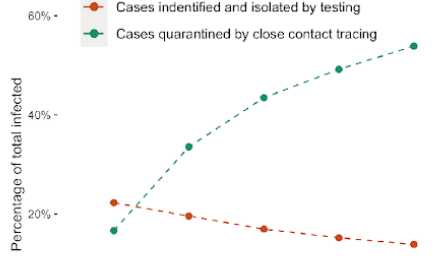

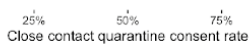

Contact structure: Non-slum urban Strategy: Antigen RDT + PCR
Contact structure: Slum

Strategy: Symptom + limited PCR
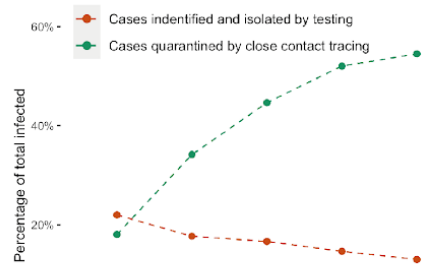

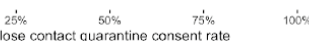

Contact structure: Slum Strategy: Antigen RDT + limited PCR
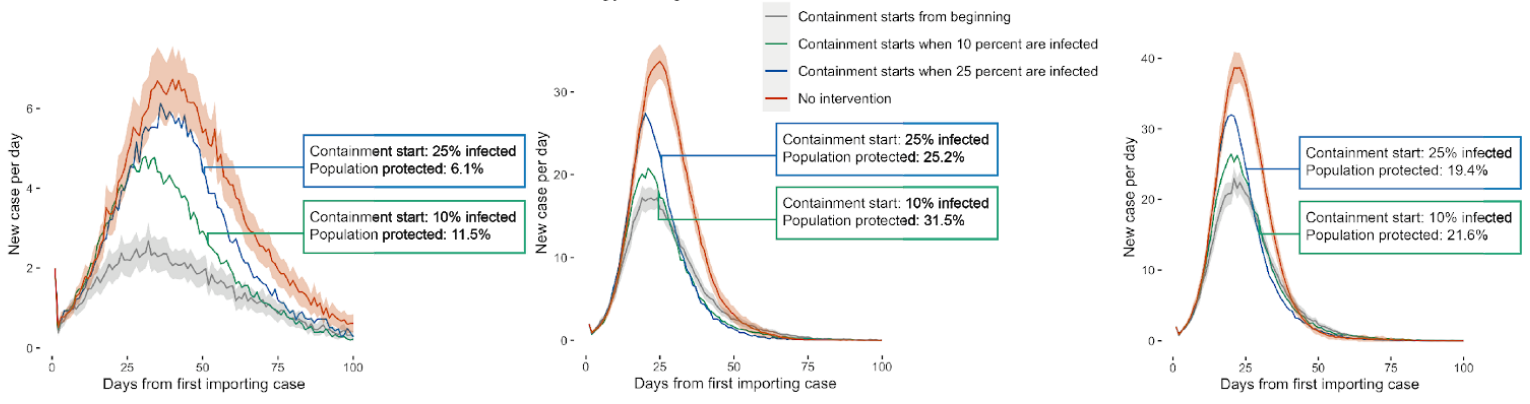

Supplementary Figure 4: Evaluation of close contact tracing and delayed responses. A)

Proportion of total cases isolated (red dots) or quarantined (green dots) varies as the compliance 
medRxiv preprint doi: https://doi.org/10.1101/2021.03.17.21253853; this version posted March 20, 2021. The copyright holder for this preprint (which was not certified by peer review) is the author/funder, who has granted medRxiv a license to display the preprint in perpetuity. It is made available under a CC-BY-ND 4.0 International license .

rate of quarantine a close contact of a confirmed case changes. B) Implementation of containing measures after a certain proportion of the population was infected could still protect a proportion of the population, compared to the circumstances with no intervention. All simulations are performed for rural, non-slum urban and slum settings.

\section{References}

Anderson, R. M., Heesterbeek, H., Klinkenberg, D., \& Hollingsworth, T. D. (2020). How will country-based mitigation measures influence the course of the COVID-19 epidemic? The Lancet, 395(10228), 931-934.

Baqui, P., Bica, I., Marra, V., \& Ercole, A. (2020). Ethnic and regional variations in hospital mortality from COVID-19 in Brazil: a cross-sectional observational study. The Lancet Global. https://www.sciencedirect.com/science/article/pii/S2214109X20302850

Bock, P., Phiri, C., Piwowar-Manning, E., Kosloff, B., Mandla, N., Young, A., James, A., Schaap, A., Scheepers, M., Donnell, D., Griffith, S., El-Sadr, W., Shanaube, K., Beyers, N., Hayes, R., Fidler, S., Ayles, H., \& HPTN 071 (PopART) Study Team. (2017). Understanding low sensitivity of community-based HIV rapid testing: experiences from the HPTN 071 (PopART) trial in Zambia and South Africa. Journal of the International AIDS Society, 20(Suppl 6), 21780.

Bong, C.-L., Brasher, C., Chikumba, E., McDougall, R., Mellin-Olsen, J., \& Enright, A. (2020). The COVID-19 Pandemic: Effects on Low- and Middle-Income Countries. Anesthesia and Analgesia, 131(1), 86-92.

Brauner, J. M., Mindermann, S., Sharma, M., Johnston, D., Salvatier, J., Gavenčiak, T., Stephenson, A. B., Leech, G., Altman, G., Mikulik, V., Norman, A. J., Monrad, J. T., Besiroglu, T., Ge, H., 
medRxiv preprint doi: https://doi.org/10.1101/2021.03.17.21253853; this version posted March 20, 2021. The copyright holder for this preprint (which was not certified by peer review) is the author/funder, who has granted medRxiv a license to display the preprint in perpetuity. It is made available under a CC-BY-ND 4.0 International license .

Hartwick, M. A., Teh, Y. W., Chindelevitch, L., Gal, Y., \& Kulveit, J. (2021). Inferring the effectiveness of government interventions against COVID-19. Science, 371(6531). https://doi.org/10.1126/science.abd9338

Corman, V. M., Landt, O., Kaiser, M., Molenkamp, R., Meijer, A., Chu, D. K., Bleicker, T., Brünink, S., Schneider, J., Schmidt, M. L., Mulders, D. G., Haagmans, B. L., van der Veer, B., van den Brink, S., Wijsman, L., Goderski, G., Romette, J.-L., Ellis, J., Zambon, M., ... Drosten, C. (2020). Detection of 2019 novel coronavirus (2019-nCoV) by real-time RT-PCR. Euro Surveillance: Bulletin Europeen Sur Les Maladies Transmissibles = European Communicable Disease Bulletin, 25(3). https://doi.org/10.2807/1560-7917.ES.2020.25.3.2000045

Davies, N. G., Klepac, P., Liu, Y., Prem, K., Jit, M., Eggo, R. M., Group, C. C.-19 W., \& Others. (2020). Age-dependent effects in the transmission and control of COVID-19 epidemics. MedRxiv. https://www.medrxiv.org/content/medrxiv/early/2020/03/27/2020.03.24.20043018.full.pdf Department of Economic and Social Affairs. (2020). World Population Prospects 2019 - Volume II: Demographic Profiles. United Nations.

El-Sadr, W. M., \& Justman, J. (2020). Africa in the Path of Covid-19. The New England Journal of Medicine. https://www.nejm.org/doi/full/10.1056/NEJMp2008193

Ferretti, L., Wymant, C., Kendall, M., Zhao, L., Nurtay, A., Abeler-Dörner, L., Parker, M., Bonsall, D., \& Fraser, C. (2020). Quantifying SARS-CoV-2 transmission suggests epidemic control with digital contact tracing. Science, 368(6491). https://doi.org/10.1126/science.abb6936

Food and Agriculture Organization. (2018). Guidelines on defining rural areas and compiling indicators for development policy. Food and Agriculture Organization of the United Nation.

Hasell, J., Mathieu, E., Beltekian, D., Macdonald, B., Giattino, C., Ortiz-Ospina, E., Roser, M., \& Ritchie, H. (2020). A cross-country database of COVID-19 testing. Scientific Data, 7(1), 345.

Hinch, R., Probert, W. J. M., Nurtay, A., Kendall, M., \& Wymatt, C. (2020). OpenABM-Covid19-an 
medRxiv preprint doi: https://doi.org/10.1101/2021.03.17.21253853; this version posted March 20, 2021. The copyright holder for this preprint (which was not certified by peer review) is the author/funder, who has granted medRxiv a license to display the preprint in perpetuity. It is made available under a CC-BY-ND 4.0 International license .

agent-based model for non-pharmaceutical interventions against COVID-19 including contact tracing. medRxiv. https://www.medrxiv.org/content/10.1101/2020.09.16.20195925v1.abstract

Hodgins, S., \& Saad, A. (2020). Will the Higher-Income Country Blueprint for COVID-19 Work in Lowand Lower Middle-Income Countries? Global Health, Science and Practice, 8(2), 136-143.

Jacobs, J., Kühne, V., Lunguya, O., Affolabi, D., Hardy, L., \& Vandenberg, O. (2020). Implementing COVID-19 (SARS-CoV-2) Rapid Diagnostic Tests in Sub-Saharan Africa: A Review. Frontiers of Medicine, 7, 557797.

Krueger, L. J., Gaeddert, M., Koeppel, L., \& Bruemmer, L. (2020). Evaluation of the accuracy, ease of use and limit of detection of novel, rapid, antigen-detecting point-of-care diagnostics for SARS-CoV-2. medRxiv. https://www.medrxiv.org/content/10.1101/2020.10.01.20203836v1.abstract

Kumar, S., Gosain, M., Sharma, H., Swetts, E., Amarchand, R., Kumar, R., Lafond, K. E., Dawood, F. S., Jain, S., Widdowson, M.-A., Read, J. M., \& Krishnan, A. (2018). Who interacts with whom? Social mixing insights from a rural population in India. PloS One, 13(12), e0209039.

le Polain de Waroux, O., Cohuet, S., Ndazima, D., Kucharski, A. J., Juan-Giner, A., Flasche, S., Tumwesigye, E., Arinaitwe, R., Mwanga-Amumpaire, J., Boum, Y., Nackers, F., Checchi, F., Grais, R. F., \& Edmunds, W. J. (2018). Characteristics of human encounters and social mixing patterns relevant to infectious diseases spread by close contact: a survey in Southwest Uganda. BMC Infectious Diseases, 18(1), 172.

Li, Z., Yi, Y., Luo, X., Xiong, N., Liu, Y., Li, S., Sun, R., Wang, Y., Hu, B., Chen, W., Zhang, Y., Wang, J., Huang, B., Lin, Y., Yang, J., Cai, W., Wang, X., Cheng, J., Chen, Z., .. Ye, F. (2020). Development and clinical application of a rapid IgM-IgG combined antibody test for SARS-CoV-2 infection diagnosis. Journal of Medical Virology, 92(9), 1518-1524.

Makoni, M. (2020). COVID-19 in Africa: half a year later. The Lancet Infectious Diseases, 20(10), 1127. Mossong, J., Hens, N., Jit, M., Beutels, P., \& Auranen, K. (2017). POLYMOD social contact data. 
medRxiv preprint doi: https://doi.org/10.1101/2021.03.17.21253853; this version posted March 20, 2021. The copyright holder for this preprint (which was not certified by peer review) is the author/funder, who has granted medRxiv a license to display the preprint in perpetuity. It is made available under a CC-BY-ND 4.0 International license .

https://datacompass.lshtm.ac.uk/1451/

Murthy, S., Leligdowicz, A., \& Adhikari, N. K. J. (2015). Intensive care unit capacity in low-income countries: a systematic review. PloS One, 10(1), e0116949.

Nishiura, H., Kobayashi, T., Miyama, T., Suzuki, A., Jung, S.-M., Hayashi, K., Kinoshita, R., Yang, Y., Yuan, B., Akhmetzhanov, A. R., \& Linton, N. M. (2020). Estimation of the asymptomatic ratio of novel coronavirus infections (COVID-19). International Journal of Infectious Diseases: IJID: Official Publication of the International Society for Infectious Diseases, 94, 154-155.

Nkengasong, J. (2020). Let Africa into the market for COVID-19 diagnostics. Nature, 580(7805), 565.

Nkengasong, J. N., Ndembi, N., Tshangela, A., \& Raji, T. (2020). COVID-19 vaccines: how to ensure Africa has access. https://www.nature.com/articles/d41586-020-02774-8?faodatalab=2020-10-06-2

Nogrady, B. (2020). What the data say about asymptomatic COVID infections. Nature, 587(7835), $534-535$.

Nordling, L. (2020). The pandemic appears to have spared Africa so far. Scientists are struggling to explain why. Science. https://doi.org/10.1126/science.abe2825

Omori, R., Matsuyama, R., \& Nakata, Y. (2020). The age distribution of mortality from novel coronavirus disease (COVID-19) suggests no large difference of susceptibility by age. Scientific Reports, 10(1), 16642.

Organization, W. H., \& Others. (2020). Scientific Brief. Advice on the use of point-of-care immunodiagnostic tests for COVID-19. 8 April 2020.

Pilarowski, G., Lebel, P., Sunshine, S., Liu, J., Crawford, E., Marquez, C., Rubio, L., Chamie, G., Martinez, J., Peng, J., Black, D., Wu, W., Pak, J., Laurie, M. T., Jones, D., Miller, S., Jacobo, J., Rojas, S., Rojas, S., ... DeRisi, J. (2020). Performance characteristics of a rapid SARS-CoV-2 antigen detection assay at a public plaza testing site in San Francisco. medRxiv : The Preprint Server for Health Sciences. https://doi.org/10.1101/2020.11.02.20223891 
medRxiv preprint doi: https://doi.org/10.1101/2021.03.17.21253853; this version posted March 20, 2021. The copyright holder for this preprint (which was not certified by peer review) is the author/funder, who has granted medRxiv a license to display the preprint in perpetuity. It is made available under a CC-BY-ND 4.0 International license.

Porte, L., Legarraga, P., Vollrath, V., \& Aguilera, X. (2020). Evaluation of novel antigen-based rapid detection test for the diagnosis of SARS-CoV-2 in respiratory samples. International Journal of. https://www.sciencedirect.com/science/article/pii/S1201971220304057

Prem, K., Cook, A. R., \& Jit, M. (2017). Projecting social contact matrices in 152 countries using contact surveys and demographic data. PLoS Computational Biology, 13(9), e1005697.

Robins, G., Pattison, P., Kalish, Y., \& Lusher, D. (2007). An introduction to exponential random graph (p*) models for social networks. Social Networks, 29(2), 173-191.

Scohy, A., Anantharajah, A., Bodéus, M., Kabamba-Mukadi, B., Verroken, A., \& Rodriguez-Villalobos, H. (2020). Low performance of rapid antigen detection test as frontline testing for COVID-19 diagnosis. Journal of Clinical Virology: The Official Publication of the Pan American Society for Clinical Virology, 129, 104455.

Shapiro, A. E., Variava, E., Rakgokong, M. H., Moodley, N., Luke, B., Salimi, S., Chaisson, R. E., Golub, J. E., \& Martinson, N. A. (2012). Community-based targeted case finding for tuberculosis and HIV in household contacts of patients with tuberculosis in South Africa. American Journal of Respiratory and Critical Care Medicine, 185(10), 1110-1116.

Shen, M., Zhou, Y., Ye, J., Abdullah Al-Maskri, A. A., Kang, Y., Zeng, S., \& Cai, S. (2020). Recent advances and perspectives of nucleic acid detection for coronavirus. Journal of Pharmaceutical Analysis, 10(2), 97-101.

Sun, K., Wang, W., Gao, L., Wang, Y., Luo, K., Ren, L., Zhan, Z., Chen, X., Zhao, S., Huang, Y., Sun, Q., Liu, Z., Litvinova, M., Vespignani, A., Ajelli, M., Viboud, C., \& Yu, H. (2020). Transmission heterogeneities, kinetics, and controllability of SARS-CoV-2. Science. https://doi.org/10.1126/science.abe2424

United Nation. (2017). Household Size and Composition Around the World 2017 [Data set]. https://www.un.org/development/desa/pd/content/household-size-and-composition-around-world-20 
medRxiv preprint doi: https://doi.org/10.1101/2021.03.17.21253853; this version posted March 20, 2021. The copyright holder for this preprint

(which was not certified by peer review) is the author/funder, who has granted medRxiv a license to display the preprint in perpetuity.

It is made available under a CC-BY-ND 4.0 International license .

17-data-booklet

Walker, P. G. T., Whittaker, C., Watson, O. J., Baguelin, M., Winskill, P., Hamlet, A., Djafaara, B. A.,

Cucunubá, Z., Olivera Mesa, D., Green, W., Thompson, H., Nayagam, S., Ainslie, K. E. C., Bhatia,

S., Bhatt, S., Boonyasiri, A., Boyd, O., Brazeau, N. F., Cattarino, L., ... Ghani, A. C. (2020). The

impact of COVID-19 and strategies for mitigation and suppression in low- and middle-income

countries. Science, 369(6502), 413-422.

Wölfel, R., Corman, V. M., Guggemos, W., Seilmaier, M., Zange, S., Müller, M. A., Niemeyer, D., Jones,

T. C., Vollmar, P., Rothe, C., Hoelscher, M., Bleicker, T., Brünink, S., Schneider, J., Ehmann, R.,

Zwirglmaier, K., Drosten, C., \& Wendtner, C. (2020). Virological assessment of hospitalized patients with COVID-2019. Nature, 581(7809), 465-469.

Wu, F., Wang, A., Liu, M., Wang, Q., Chen, J., Xia, S., Ling, Y., Zhang, Y., Xun, J., Lu, L., Jiang, S., Lu, H., Wen, Y., \& Huang, J. (2020). Neutralizing Antibody Responses to SARS-CoV-2 in a COVID-19

Recovered Patient Cohort and Their Implications. https://doi.org/10.2139/ssrn.3566211

Wu, Z., \& McGoogan, J. M. (2020). Characteristics of and important lessons from the coronavirus disease 2019 (COVID-19) outbreak in China: summary of a report of 72314 cases from the Chinese Center for Disease Control and Prevention. JAMA: The Journal of the American Medical Association, 323(13), 1239-1242.

Zhang, J., Litvinova, M., Liang, Y., Wang, Y., Wang, W., Zhao, S., Wu, Q., Merler, S., Viboud, C., Vespignani, A., Ajelli, M., \& Yu, H. (2020). Age profile of susceptibility, mixing, and social distancing shape the dynamics of the novel coronavirus disease 2019 outbreak in China. medRxiv : The Preprint Server for Health Sciences. https://doi.org/10.1101/2020.03.19.20039107

Zhu, N., Zhang, D., Wang, W., Li, X., Yang, B., Song, J., Zhao, X., Huang, B., Shi, W., Lu, R., Niu, P., Zhan, F., Ma, X., Wang, D., Xu, W., Wu, G., Gao, G. F., Tan, W., \& China Novel Coronavirus Investigating and Research Team. (2020). A Novel Coronavirus from Patients with Pneumonia in 
medRxiv preprint doi: https://doi.org/10.1101/2021.03.17.21253853; this version posted March 20, 2021. The copyright holder for this preprint (which was not certified by peer review) is the author/funder, who has granted medRxiv a license to display the preprint in perpetuity.

It is made available under a CC-BY-ND 4.0 International license .

China, 2019. The New England Journal of Medicine, 382(8), 727-733. 